\title{
Toplumsal Cinsiyet ve Medya: Şule Çet'in Şüpheli Ölümü Üzerine Haberlerin Eleştirel Söylem Analizi
}

\author{
Zeynep Burcu Şahin (Dr. Öğr. Üyesi) \\ İstanbul Gelişim Üniversitesi Uygulamalı Bilimler Yüksekokulu \\ zbsahin@gelisim.edu.tr \\ ORCID: 0000-0003-1870-3073 \\ Yıldız Derya Birincioğlu (Dr. Öğr. Üyesi) \\ İstanbul Gelişim Üniversitesi Uygulamalı Bilimler Yüksekokulu \\ deryabirincioglu@gmail.com \\ ORCID: 0000-0003-0119-9341
}

Başvuru Tarihi: 27.07.2019

Yayına Kabul Tarihi: 29.11.2019

Yayınlanma Tarihi: 24.01.2020

DOI: http://10.17680/erciyesiletisim.597502

\section{öz}

Toplumsal cinsiyet kavramı, kişinin biyolojik cinsiyetinden farklı olarak bireyin toplumsallaşma süreci içerisinde cinsiyete ilişkin edindiği kalıplar, yargılar ve önyargılar olarak adlandırılabilir. Toplumsal cinsiyet, bireyin sosyalleşme süreci ile birlikte ortaya çıkan sosyo-kültürel bir olgudur. Geleneksel toplumlarda ikincil gruplar aleyhine kurulan toplumsal cinsiyet düzeninin pekiştirilmesinde ve sürdürülmesinde başat rol oynayan medya, söylemin gücüyle toplumsal cinsiyet ve toplumsal cinsiyete dayalı şiddeti meşru kılmakta ve yaygınlaştırmaktadır. Çalışma, bu bağlamda yeni medya üzerinden gündem oluşturulan ve daha sonra ana akım medya gündemine de yerleșen Şule Çet'in şüpheli ölümü üzerine Sabah gazetesinin dijital versiyonunda 01.06.2018-18.06.2019 tarihleri arasında yer alan haberlerin incelenmesini içermektedir. Çalışmanın amacı, Sabah gazetesi örneğinde kadına yönelik şiddet ve tecavüz haberlerinde kullanılan cinsiyetçi söylemlerin tespit edilerek toplumsal cinsiyet odaklı haberciliğe ilişkin önerilerin sunulmasıdır. Çalıșmada Van Dijk'in eleștirel söylem analizi yöntemi esas alınmaktadır. Toplumsal cinsiyet odaklı haberciliğe ilişkin verilerin ortaya çıkarılmasında kullanılan eleștirel söylem analizi dil formları içerisinde örtük bir biçimde yer alan anlam ve ideolojilerin bulunmasını sağlar ve iktidar, söylem ve ideoloji arasındaki ilişkiyi medya içerikleri aracılığıyla incelemek için alan yaratır. Kadına şiddeti içeren haberler söz konusu olduğunda başlık, haber fotoğrafı, kelime seçimi, cümle yapısı vb. mikro ve makro yapıların nasıl kurgulandığı azami önem taşımaktadır. Bu doğrultuda medyanın toplumsal cinsiyet odaklı haber anlayıșını reyting/tiraj/tıklanma kaygısının önüne koyması ve toplumsal sorumluluk anlayışı çerçevesinde toplumsal cinsiyet eşitliğini destekleyici bir yayın politikası uygulama hususunda gerekli adımları atması gerekmektedir.

Anahtar Kelimeler: Medya, Kadına Şiddet, Eleştirel Söylem Analizi, Toplumsal Cinsiyet. 


\title{
Gender and the Media: Critical Discourse Analysis of the News on The Suspect Death of Şule Çet
}

\author{
Zeynep Burcu Şahin (Asst. Prof. Dr.) \\ İstanbul Gelişim University School of Applıed Scıences \\ zbsahin@gelisim.edu.tr \\ ORCID: 0000-0003-1870-3073 \\ Yıldız Derya Birincioğlu (Asst. Prof. Dr.) \\ İstanbul Gelișim University School of Applıed Scıences \\ deryabirincioglu@gmail.com \\ ORCID: 0000-0003-0119-9341
}

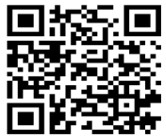

Date Received: 27.07.2019

Date Accepted: 29.11.2019

Date Published: 24.01.2020

DOI: http://10.17680/erciyesiletisim.597502

\begin{abstract}
Gender can be called as stereotypes, judgments and prejudices acquired by the individual in the process of socialization. Gender is a socio-cultural phenomenon that occurs with the individual's socialization process. Media, which plays a major role in strengthening and sustaining the gender order established against secondary groups in traditional societies, legitimizes and promotes gender-based violence with the power of discourse. In this context, the study includes the analysis of the news on the suspicious death of Şule Çet, who was put on the agenda of the new media and then settled on the mainstream media agenda, in the digital version of Sabah newspaper between the dates 01.06.201818.06.2019. The aim of this study is to identify the sexist rhetoric used in the news of violence and rape against women in the Sabah newspaper and to present suggestions for gender-oriented journalism. The study is based on Van Dijk's method of critical discourse analysis. Critical discourse analysis, which is used to uncover data on gender-oriented journalism, implicitly finds meaning and ideologies in language forms and creates space to examine the relationship between power, discourse and ideology through media contents. When it comes to news of violence against women, the title, news photo, word selection, sentence structure and so on. How micro and macro structures are constructed is of utmost importance. In this direction, the media should put the gender-oriented news approach in front of rating / circulation / click concerns and take the necessary steps to implement a publication policy that supports gender equality within the framework of social responsibility.
\end{abstract}

Keywords: Media, Violence against Women, Critacal Discourse Analysis, Gender. 


\section{Giriş}

Söylem analizi çerçevesinde, dilin ve temsilin nasıl üretildiğinin yanı sıra, temsil, anlam ve iktidar arasındaki ilişkiler, kimlikler ve öznelliklerin oluşumu incelenmektedir (Yardım ve Doğruel, 2018, s. 137). Van Dijk'e göre söylem, ideolojilerin yeniden üretiminde ve günlük ifadelerde başat bir rol oynamaktadır (2003, s. 13). İdeolojiler ise toplumdaki iktidar ilişkileri sonucunda ortaya çıkmakta ve bir toplumsal grubun diğeri üzerinde tahakküm kurmasının meşru zeminini oluşturmaktadır. Bu anlamda söylem, ideoloji ve iktidarın birbirlerinden beslenen kavramlar olduğunu söylemek mümkündür.

Eleştirel söylem analizi, haber metinlerinde yer alan ideolojik unsurların dil formları içerisinde örtük bir biçimde yer aldığını öne sürer (Güneş, 2018, s. 13). Toplumsal ve kültürel yapı içerisinde egemen yapı lehine inşa edilen söylemler, haber metinleri içerisinde yeniden inşa edilir, meșrulaştırılır ve yaygınlık kazandırılır. Eleștirel söylem analizinde amaç, söylemin altında örtük bir biçimde yer alan ideolojinin ortaya çıkarılıp öznel bir yorumunun ortaya konması ve görünmeyen anlamların ortaya çıkarılmasıdır.

Van Dijk, bir grubun diğer bir grup üzerine tahakküm kurmasında veya var olan iktidar ilișkilerinin yeniden üretilmesinde söylemin gücü üzerinde durmuştur (Akt. Okray, 2018, s. 193). Haber söylemlerinin dilbilimsel ve görüntü açıdan çözümlenmesi ise toplumsal eşitsizliklerin nasıl yeniden üretildiğini ortaya koyacaktır (Özer, 2008, s. 400). Eleştirel söylem analizi, dilin görünen anlamı dıșında dizgesel özelliklerine ve yapı unsurlarının birbirleriyle ilişkilerine de odaklanır.

Bu çalışmanın konusunu, Şule Çet'in ölümü üzerine yazılı basında yer alan haber içerikleri oluşturmaktadır. Şule Çet, 28 Mayıs 2018 tarihinde Çankaya'da bir plazada işverenleri ile buluşmuş ve gecenin sonunda plazanın 20. katından düşerek/atılarak ölmüştür. Gazeteler tarafından şüpheli olarak görülen haber konusu olay, geçtiğimiz bir yıl boyunca yeni medyanın öncülügüyle dönem dönem gündeme getirilmiş ve șüphelilerin yargılanması adına kamuoyu baskısı oluşturulmuştur. Bu çalışmanın amacı, ilk bakışta mağdur temelli görünen haber içeriklerinin eleştirel söylem analizi yoluyla çözümlenmesi ve içeriklerde inşa edilen iktidar eşitsizliklerinin ve kadın aleyhine şekillendirilen toplumsal cinsiyet olgusunun ortaya koyulmasıdır.

\section{Toplumsal Cinsiyet Kavramı}

TDK cinsiyeti “bireye, üreme işinde ayrı bir rol veren ve erkekle dişiyi ayırt ettiren yaradılış özelliği, eșey, cinslik, seks" olarak tanımlamaktadır. Toplumsal cinsiyet ise cinsiyetten farklı olarak doğuştan gelen özelliklerden ziyade toplumsallaşma süreci içerisinde kadın ve erkeğin takındıkları farklı rollere ve özelliklere işaret etmektedir.

Toplumsal cinsiyet kavramı, ilk defa 1972 yılında Ann Oakley'ın Sex, Gender and Society adlı eserinde kullanılmış olmakla birlikte (Oakley, 2016) kadının toplumdaki yeri üzerine çalışmalar daha eskilere ikinci dalga feminist hareketin yükselişe geçtiği 1940’lı yıllara dayanmaktadır (Baştürk Akca ve Ergül, 2016, s. 17). Kadının toplum içindeki ikincil konumunu sorgulayan ikinci dalga feministler, toplumsal cinsiyet, iktidar ve cinsellik konularını ataerkil toplum yapısında sorunsallaştırmaktadır (Baştürk Akca ve Tönel, 2011, s. 16).

Toplumsal cinsiyet, toplum içinde yaşayan bireylere doğuştan sahip oldukları cinsiyet özelliklerinden yola çıkılarak atfedilen, hak, görev ve sorumlulukları ifade etmektedir. Her toplumda ve çağda kavramın içeriğinde bazı değişiklikler görülse de (Yeşil ve Yıldırım, 2018, s. 235) kavram temelde, günümüzde genel olarak hâkimiyetini 
sürdüren ataerkil toplum yapısına uygun biçimde kadına yönelik gerçekleştirilen negatif ayrımcılığı ve yüzyıllardır kamusal alandan dışlanan kadının toplumdaki yerini sorgulamayı içermektedir.

Judith Butler, toplumsal cinsiyet kavramına dair genelleştirilebilir ya da evrensel kodların mümkün olmadığını, kavramın toplumsal olarak inşa edildiğini ve iktidar ilişkilerinden bağımsız düşünülemeyeceğini belirtir. Butler, Cinsiyet Belası adlı eserinde cinsiyetin kurgusal bir yapıya sahip olduğunu ve jestler ya da konuşma gibi eylemler ile ifade edilemeyeceğini söyler. Cinsiyetin kurgusal yapısında erkek bedenleri evrensel kişiliğin taşıyıcısı olarak konumlandırılırken kadın bedenleri ise ataerkil düzenin belirlediği kurallar ile sınırlandırılmaktadır. Erkek hegemonyası ve iktidar mücadelesi tarafından özel ve kamusal alanlarda üretilen temsil ve uygulamalara uymayan kadınlar ya da erkekler, dışlanma ya da cezalandırma pratikleri ile toplumsal cinsiyet düzeninin dışında konumlandırılır (Butler, 2014, s. 50-52). Böylelikle heteronormatif düzenin ${ }^{1}$ işlerlik kazanması, temsil pratiklerine uygun kurgu türlerinin genişletilmesi ve bu kurgu türlerine uyum ile geçerlilik kazanır.

"Toplumsal cinsiyet kavramı, kadın ve erkeği tanımlayan biyolojik özellikleri belirten cinsiyet kavramından ayrı olarak, karmaşık toplumsal ilişkiler ağı içinde inşa edilen nitelikleri, kadınlık ve erkekliğe yüklenen anlamları, onlardan beklenen davranışları ifade etmek için kullanılır" (Akca ve Ergül, 2016, s.17). Bu anlamlar toplumdan topluma farklılık gösterebileceği gibi aynı toplum içinde de zaman içinde değişiklik gösterebilir. Bir toplumun farklı kesimlerinin cinsiyete yüklediği anlamlar birbirinden farklı olabilir. Bununla birlikte günümüzde toplumsal cinsiyet kavramı genel olarak ataerkil toplum yapısı ile ilişkilendirilerek eleştirel bir anlam kazanmaktadır. Nitekim Sakallı'ya göre toplumsal cinsiyet kavramı, ataerkil toplum yapısında kadına yönelik olumsuz davranışların yansıması ile kadının sosyal, kültürel ve ekonomik bağlamda erkekten düşük konumlandırılmasını içermektedir (Akt. Budak ve Küşükşen, 2018, s. 562). Toplumsal cinsiyet kavramı, Deniz Kandiyoti'nin "Ataerkil Pazarlık" kavramsallaștırması dâhilinde de düşünülebilir. Kandiyoti (2007, s. 114) ataerkil toplumların cinsiyet rollerine dair farklı bakış açısı geliştirmede ürettiği bu anahtar kavramsallaştırma ile kadınların tâbiyet sürecinde kendilerine yeni bir alan yarattığını ifade eder. Ataerkil pazarlıkta ataerkil ilişkiler ya da anlayışlar her iki cinsiyetin de rıza gösterdiği bir pratik ile korunma ve güvenceye altına alınır. Kadınlar uyumluluk ve tâbiyet gösterdiği sürece kamusal alanda kaybettikleri alanlarını özel alanda kazanmaya başlar. Bu pazarlık ile toplumsal cinsiyet ilişkileri yeniden kurulur ve kadın özel alanda daha güçlü olduğu bir konumlandırmaya sahip olur. Bu pazarlığın niteliği, toplumsal ve kültürel farklılıklar taşımaktadır. Kadın, hangi alanda pasif hangi alanda aktif olacağını hiyerarşik ilişki ile girdiği pazarlık boyutuna göre belirlemektedir.

Connell ise toplumsal cinsiyet düzenini "erkeklerle kadınlar arasında ve kadınlık tanımıyla erkeklik tanımı arasında tarihsel olarak kurulmuş bir iktidar ilişkileri örüntüsü" olarak tanımlamaktadır. Connell'e (1998, s. 245) göre bu iktidar ilişkileri örüntüsünün erkekler tarafından üretilme sebebi hegemonik olmayan erkekleri suç ortaklığına teşvik etmek ve kadınların erkeklere bağımlı kılınmasını sağlamaktır. Zorlama ve baskı yerine rıza aracılığıyla sağlanan bu iktidar örüntüleri, hegemonik erkekliğin etki alanını güçlendirirken heteronormatif cinsiyet politikalarının da belirginlik kazanmasını sağlar. Bu noktada, heteronormatif cinsiyet politikaları, üç temel alanda etkinlik göstermektedir; emek, iktidar ve cinsellik. Erkek egemenliği bu üç alanda da birbirlerini desteklemekte ve özel yaşamdan kamusal yaşama, tüm kurumlarda ve söylem biçimlerinde kadını ikincil 
bir plana sürüklemektedir (Saygılıgil, 2016, s. 11). Mathieu (2009, s. 83) da toplumsal cinsiyetin iki temel alanda kendini gösterdiğini ifade etmektedir; birincisi üretim araçlarının bölünmesi ve iş bölümü, ikincisi ise üreme emeğinin toplumsal bölünüşüdür. Connell'a göre iş bölümü, iktidar yapısı ve kateksis yapısı, toplumsal cinsiyet düzeninin ana unsurlarını oluşturmaktadır (2017, s. 14). Tarihsel süreçte iktidarı ele geçiren erkek, önce emek piyasasında iş bölümünü kendi cinsi lehine değiştirmiş; sonrasında ise tehdit olarak gördüğü kadının cinselliğini din, hukuk ve toplumsal kurallar yoluyla baskı altına almıştır.

\begin{abstract}
“Erkek egemenliğinin kuruluşu, kadınlara tekeşli evlilikler dışında cinselliği yasaklarken, erkeklere evlilik içinde ve dışında mümkün olduğunca serbestlik sunar. Türkiye'de erkeklerin cinsel deneyimleri -farklı bir erkeklik inşası bağlamıyla karşılaşmadıkları sürece - çoğu zaman erkeklerin 'eğlenme' gerekçesiyle gittikleri yerlerde, eğlenme adına kadın bedeninin aşağılanıp satıldığı, metalaştırıldığı genelevlerde, pavyonlarda şekillenmektedir" (Sancar, 2009, s. 196).
\end{abstract}

Erkek, erilliğini homososyal ortamlarda yeniden üreterek toplumsal cinsiyet düzenini normalleştirir. Homososyallik, kendi cinsiyet grubuna ait kişilerin bir arada bulunduğu ve erkeklik bağının güçlendirildiği alanlardır. Bu sosyal ve fiziki alanlarda, hem siyasi, ahlaki konular tartışılır; hem de güç ilişkileri inşa edilir (Lipman-Blumen, 1976, s. 16; Meuser, 2004, s. 396). Hegemonik erkeklik düzeni, erkeklerin kadınlardan daha güçlü olduğunu düşündüğü ve kadınları boyunduruk altına almaya çalıştığı bir yapıya dayanır. Toplum içinde yer alan farklı erkeklik öğretileri, anlatıları ve modelleri birbiriyle yarışır. Kabul gören, kutsanan, desteklenen ve takdir edilenler, homososyal ortamlarda yeniden inşa edilir. Erkeklik özellikle iki mekânda üretilir. Bunlardan ilki erkeklere özgü olan ve kadınların dışlandığı ya da konuk olarak yer aldıkları mekânlardır: Erkek hamamları, kıraathaneler, erkek yurtları/okulları, askeri kışlalar, camiler, kamyoncu durakları. İkinci olarak ise kadın ve erkeğin ortaklaşa yer aldıkları ve mekânsal iş bölümü gerçekleştirdikleri yerler: striptiz kulüpleri, pavyonlar, randevuevleri vs. (Özbay, 2013, s. 192). Bu mekânlarda üretilen kimliklere ilişkin kodlar, özel ve kamusal alanlarda pekiştirilerek toplumsal cinsiyet düzeninin kurulması sağlanır. Heteronormatif ideolojiyi tehlikeye düşürecek her olgu, eril tahakküm ile baskı altına alınır. Böylelikle, hem doğacak erkeklik krizlerinin önüne geçilir; hem de kadın ona uygulanan sembolik şiddet ve güç ile madunlaştırılabilir. Kadının konumlandırılmasındaki en temel güçlerden biri olan şiddet, tam olarak burada devreye girmektedir. Bu sebeple, çalışmada toplumsal cinsiyet düzeni ve şiddet arasındaki ilişkiye değinmek iki olgu arasındaki girift bağı yorumlamak için etkili olabilir.

\title{
Medya ve Şiddet
}

Şiddet, Dünya Sağlık Örgütü (WHO) tarafından, "fiziksel güç veya iktidarın kasıtlı bir tehdit veya gerçeklik biçiminde bir başkasına uygulanması sonucunda maruz kalan kişide yaralanma, ölüm ve psikolojik zarara yol açması ya da açma olasılığı bulunması" durumu olarak tanımlanmaktadır (www.who.int). Şiddet, toplumdaki iktidar ilişkilerinin bir sonucu olarak ortaya çlkmakta ve şiddetin nesnesini çoğunlukla toplumun "öteki" olarak yaftaladığı ikincil gruplar oluşturmaktadır (Erol, 2014, s. 31). Toplumun biz kavramının cinsiyet, ırk, köken, cinsel eğilim, dini inanç vb. özellikleri dışında kalan “öteki”lerin başında ise kadın gelmektedir. Kadın başta cinsiyetinden kaynaklı olarak madunlaştırılmaktadır.

Toplumsal cinsiyet ilişkilerinden kaynaklanan şiddet, toplumun kadın ve erkek tanımlarından yola çıkmakta ve genel kabul görmüş tanımların dışına çıkan/dışında kalan kadın ve erkeklere uygulanmaktadır (Erol, 2014, s. 31). Toplumun genelinin ona 
tanıdığı rolün dışına çıkmayı göze alan (örneğin boşanmak isteyen ya da boşanan, evlilik dışı cinsel ilişki yaşayan, sevilisinden/nişanlısından ayrılan, toplumun onaylamadığı bir biçimde giyinmeyi tercih eden vb.) kadın şiddetle karşılaştığında yukarıda saydığımız niteliklerin altı çizilmek suretiyle şiddetle bu sebepler arasında nedensellik ilişkisi kurulmaya çalışılmaktadır.

\begin{abstract}
"Var olan toplumsal cinsiyet ilişkilerinde erkek, kadınlardan farklı olarak şiddet kullanabilen ve buna hakkı olan cins olarak konumlanmaktadır. Erkeğin şiddet kullanımı ise çoğu kez toplum tarafından belirlenen görevler ve bunların 'erkekte yarattığı' istek ve arzularla ilişkili olduğu görülmektedir" (Erol, 2014, s. 37).
\end{abstract}

Erkeğin bir eş, baba, abi vs. olarak karısını, kardeşini, çocuklarını disipline etmek, korumak, yönlendirmek ve ceza vermek amacıyla şiddete başvurması toplum tarafından makul ve mazur görülebilmekte; diğer yandan kadının cinselliğini ön plana çıkarıcı veya toplum tarafından "bir kadına göre fazla" olarak algılanabilecek davranışlarının erkeği cinsel şiddete yönlendirebileceği genel olarak kabul görmektedir.

Kadınlara Yönelik Şiddetin Ortadan Kaldırılmasına Yönelik Bildirge'nin 2. maddesinde kadına yönelik şiddetin aşağıda ifade edilenlerle belirlenebileceği ancak sınırlandırılamayacağı ifade edilmiştir;

“(a) Dayak ve hırpalama, ev halkına dâhil olan kız çocuklarının cinsel suiistimali, drahoma
bağlantılı şiddet, evlilik içi tecavüz, kadın cinsel organını sakatlama veya kadına zarar veren
diğer geleneksel uygulamalar, eş haricinde (ev halkına dâhil) kişilerce uygulanan şiddet,
sömürüyle bağlantılı şiddet dâhil olmak üzere aile içinde meydana gelen fiziksel, cinsel veya
psikolojik şiddet;

(b) Tecavüz, cinsel suiistimal, iş yerinde, eğitim kurumlarında veya diğer yerlerde kadınlara karşı şiddet meydana gelen cinsel taciz ve sindirme, kadın ticareti ve fahișeliğe zorlama dâhil olmak üzere genel olarak toplum içinde meydana gelen şiddet;

(c) Nerede olursa olsun devlet tarafından işlenen veya göz yumulan fiziksel, cinsel veya psikolojik şiddet."

Bianet'in verilerine göre; 2018 yılı boyunca Türkiye'de en az 255 kadın, 20 çocuk ve cinayet sırasında kadınların yanında bulunan 39 erkek, erkekler tarafından öldürülmüştür. 2018 yılında basına yansıyan tecavüz sayısı 61, taciz sayısı ise 188'dir. 516 kadın, erkekler tarafından seks işçiliğine zorlanırken 347 kız çocuğu da cinsel olarak istismar edilmiştir (Bianet.org).

Kadına yönelik cinsel şiddetin bir biçimi olan tecavüz, Bourdieu'nun $(2015$, s. 70$)$ penetrasyon ve tahakküm arasında kurduğu ilișki dâhilinde yorumlanabilir. Bourdieu, erkek şiddetinin odağında eril tahakküm ve dişil itaat mekanizmasının yer aldığını belirtir. Bu ilişkide erkek sadece fiziksel şiddet uygulayarak değil; aynı zamanda sembolik şiddet uygulayarak da kadını itaate zorunlu kılar. Erkeğin eril toplumda kabullenilmesi ve onaylanması için sembolik şiddet en belirgin araçlardan biri haline gelir. Erkek, cinsel organını bir silah gibi kullanarak kadını itaate zorlar ve kadın bedeni üzerindeki gücünü cinsel saldırı ile göstergeleştirir. Eril hegemonik gücünü mağdur üzerindeki itaat pratiği ile inşa eden erkek, kendi kimliğini toplumsal cinsiyet ideolojisinin söylemleri ile geliştirir. Kadına yönelik cinsel şiddet suçlarının toplumsal bir sorun olduğunun görülmesi ve çözüm sürecinin de yine toplumun kendisinde aranması gerekmektedir. $\mathrm{Bu}$ anlamda, iktidardaki siyasilerin söylemleri toplumun genelinin bakış açısını yansıtması ve yönlendirmesi açısından oldukça önemlidir. Topluma kanaat önderliği yapan siyasi aktörlerin şiddeti olumlayacak açıklamalar yapması, kadının hak, söylem ve roller 
bağlamında yeniden madunlaştırılmasına zemin hazırlamaktadır. Bu sebeple, sadece yasa düzleminde değil; aynı zamanda söylem ve politika düzleminde de birbirini destekleyen pratiklerin uygulanmasının, toplumsal dönüşümün gerçekleşmesinde itici bir güce sahip olduğu unutulmamalıdır.

Toplumsal cinsiyet rolleri, bașta aile olmak üzere bütün toplumsal kurumlar tarafından birbirlerini destekleyecek şekilde üretilir ve desteklenir. Eğitim, hukuk, din ve medya, aile tarafından ilk tohumları atılan toplumsal rolleri pekiştirir ve sürekli yeniden üretir.

Toplumsal bir sorun olan şiddet, haberleştirilirken çoğu zaman bireysel sebeplere (kişisel özellikler, akli dengesizlik, kişisel ekonomik sorunlar, işsizlik vb.) indirgenerek toplumun ekonomik, siyasi ve kültürel bağlamından çıkarılmaktadır. Toplumsal cinsiyete dayalı şiddette toplumun kadın ve erkeğe biçtiği roller ve uygun gördüğü davranış kalıpları başat rol oynamaktadır.

Toplumsal cinsiyet rollerinin benimsenmesi ve kalıplaşmasında siyasi aktörler kadar rol alan ve tecavüz suçlarını haberleştirirken bu kalıpları yeniden üreten ve olumlayan medyanın rolü oldukça önemlidir. Connell, Toplumsal Cinsiyet ve Íktidar adlı eserinde tecavüz haberleri ve medya arasındaki ilişkiyi şöyle yorumlamaktadır;

"Sözgelimi, medyada sürekli bireysel sapkınlık olarak sunulan tecavüz iktidar eşitsizlikleri ve erkek üstünlüğü ideolojilerine köklü biçimde yerleşmiş bir 'kişiden kişiye' şiddet biçimidir. Toplumsal düzenden sapmak bir yana dursun, en açık anlamda bu düzenin bir uygulamasıdır" (Connell, 1998, s. 150). Medya, söz konusu şiddet olaylarını toplumsal bağlamından kopararak bireysel olarak ele almakta; bir yandan sorunun temelinin anlaşılmasını engellerken, diğer yandan kullandığı eril dille yeniden üretmektedir. Bir diğer deyişle medya, tecavüz ve şiddetin iktidar eşitsizliklerinin ve patriarkal düzenin doğal bir sonucu olduğunu görmezden gelmektedir.

Bennett, şiddet olaylarının haberleştirilmesinde kişiselleştirme, dramatize etme ve normalleştirme süreçlerinin hâkim olduğunu öne sürmektedir (Akt. Erol, 2014, s. 39). Buna göre şiddet haberleri, medya tarafından kişiler arası olaylara indirgenmekte, sansasyonel habercilik çerçevesinde dramatik öğeler ön plana çıkarılarak hikayeleştirilmekte; siyasi, kültürel ve ekonomik bağlamından koparılmaktadır. Bununla birlikte, tecavüzün haberleştirilmesinde söylemin gücü ön plana çıkmakta; kullanılan dil tecavüzün meşrulaştırılmasına, toplumsal cinsiyetçi söylemin yeniden üretilmesine ve medya aracılığıyla yargılanmak istemeyen kurbanın sessiz kalmayı tercih etmesi gibi toplumsal sonuçlara yol açabilmektedir (Deniz ve Korap Özel, 2015, s. 722). Medyanın suça ilişkin haberleri toplumsal bağlamından kopararak bireysel sorunlara indirgemesi, toplum üzerinde normalleştirici ve duyarsızlaştırıcı bir etki yaratmakla birlikte (Yardım ve Doğruel, 2018, s. 140) söz konusu suçların kökenine inilememekte ve doğru çözüm yöntemleri üzerinde çalışılamamaktadır.

Benzer bir tespit de Çiler Dursun'un Kadına Yönelik Aile İçi Şiddet ve Haber Medyası: Alternatif Bir Habercilik adlı projesinde dikkat çekmektedir. Dursun'a göre, polis-adliye, toplumsal olaylar ve gösterilerle ilgili haberlerde olumsuz içerik, olumlu içeriğe oranla daha çok dikkat çekmektedir. Habere daha çok değer kattığı düşünülen bu durumun etki gücünün artırılması için haber sunumunda öldürülen kadının fotoğrafının büyük olarak verildiği; ancak haberde yer alan erkeğin fotoğrafının küçük bir portre olarak yer aldığı ya da tecavüze uğrayan kadının eski güzel günlerinden kalma çoğunlukla açık saçık giysili fotoğraflarının kullanıldığı ve tecavüzcüsünün görüntüsünün mozaiklendiği 
görülmektedir (Dursun, 2008, s.59). Dursun, bu tarz haberlerde yer alan söylemleri Butler'ın iktidar odakları ile özdeşleşme prensibinden yola çıkarak yorumladığında, söz konusu söylemlerin bireyin kimlik oluşturma süreçlerine kalıcı zararlar verdiğinin altını çizer. Kadına yönelik aile içi şiddet sorunu ile ilgili alternatif bir dil önerisinde bulunan Çiler Dursun, haberlerin kişiselleștirme ile toplumsal ve kurumsal bağlarından koparıldıklarını, ikinci düzey neden-sonuç bağına değinildiğini (kıskançlık/cinayet/ tecavüz) belirtir. Dursun, şiddet haberlerinde alternatif bir habercilik dili gelişimi için; başlıkta şiddet eyleminin yeniden üretilmemesi, şiddete maruz kalan kadının erkekle arasındaki hukuki bağın gereksiz yere kullanılmaması, olayın mağdurunun fiziksel özelliklerinin belirtilmemesi ve edilgin cümleler yerine etkin cümleler ile failin eylemlerinden sorumlu tutulması gerektiğini ifade eder (Dursun, 2008, s.85-88).

Wood, çalışmasında medyanın toplumsal cinsiyetin oluşumuna etkilerini birbirleriyle ilişkili üç boyutta incelemektedir. Birincisi, kadınlar medyada yeterince temsil edilmemektedir. İkincisi, erkekler ve kadınlar toplumsal olarak onaylanmış toplumsal cinsiyet görüşlerini yansıtan ve sürdüren klişeleșmiş yöntemlerle tasvir edilmektedir. Üçüncüsü, kadınlar ve erkekler arasındaki ilişkilerin tasviri geleneksel rolleri vurgulamakta ve kadına yönelik şiddeti normalleștirmektedir (Wood, 1994). Wood'un boyutlarından yola çıkarak, medyada kadının özellikle dizi, haber ve kadın programlarında bu üç boyuttan örneklerin sunulduğu bir temsil pratiğine sahip olduğu söylenebilir. Farklı ülke yapımları Türkiye'nin kültürel dinamiklerine dönüştürüldügünde, değișen ilk yapının kadının sunumu ve toplumsal cinsiyet rolleri olduğu görülmektedir. Kadınlar, geleneksel rollerin dışında konumlandırılmamakta; konumlandırıldığı programlar ise aile yapısını ve toplumsal cinsiyet kalıplarını bozmaları nedeni ile ötekileștirilmekte ya da cezalandırılmaktadır. Dizilerin en temel cezalandırma pratiği, tecavüz miti üzerinden şekillenmektedir ${ }^{2}$. Dizi ve kadın programları gibi kurgusal zeminlerde kadınların meta olgusu olarak üretilmesi, haberlerde yer alan temsil mekanizmalarının ve konumlandırmalarının toplumsal ve kültürel faktörlerle üretilmesine ve cinsel şiddete başvuran erkeğin normalleşmesine zemin hazırlamaktadır. Toplumsal sorunu basit indirgemeci bir yaklaşımla mağdur/kurban davranışlarında temellendiren bu bakış açısı, eril hegemonik kültür yapısının bir ürünüdür. Bu sebeple, toplumsal cinsiyet kalıplarının yanı sıra tecavüz mitleri de medyanın ve toplumun tecavüze bakışını belirlemektedir.

\footnotetext{
“Tecavüze ilişkin tutumların ve kültürel inançların çekirdeği olan 'tecavüz mitleri' (rape myths), tecavüz, tecavüzcü ve tecavüz mağduru hakkında, önyargıll, kalıplaşmış ya da yanlış inançlar olup, cinsiyet rollerine ilişkin baskın, edilgen, rekabetçi kalıpyargıları (sterotypes) olan toplumların mantıksal sonucu olarak gelişirler" (Eker ve Erdener, 2011, s. 61).
}

Tecavüz mitleri, genel itibariyle kadına yönelik erkek saldırganlığını haklı çıkarmaya yönelik yanlış inanç ve tutumlardan oluşmaktadır ve kaynağını toplumsal cinsiyet kalıplarından ve sosyal normlardan alır. Bir diğer deyişle, tecavüz mitleri sosyalleşme sürecinde öğrenilmektedir. Aşağıdaki tabloda en çok bilinen tecavüz mitleri yer almaktadır.

Tablo 1: Tecavüz mitleri (Wood, 1994).

\begin{tabular}{|l|l|}
\hline Tecavüz Miti & Gerçek \\
\hline $\begin{array}{l}\text { Tecavüz, cinsel dürtülerden } \\
\text { kaynaklanan cinsel bir eylemdir. }\end{array}$ & $\begin{array}{l}\text { Tecavüz, bir başkasına hükmetmek için } \\
\text { kullanılan saldırgan bir eylemdir. }\end{array}$ \\
\hline Tecavüzcüler anormaldir. & $\begin{array}{l}\text { Tecavüzcülerin kişilik, psikoloji, uyum ya da } \\
\text { kişilerarası ilişkilerde tecavüzcü olmayanlardan } \\
\text { farklı olmadıkları ortaya konmuştur. }\end{array}$ \\
\hline
\end{tabular}




\begin{tabular}{|l|l|}
\hline Tecavüz Miti & Gerçek \\
\hline Tecavüzlerin çoğu yabancılar arasında gerçekleşir. & $\begin{array}{l}\text { Tecavüzlerin \%80-90 arası bir oranı mağdurun } \\
\text { tanıdığı bir kişi tarafından gerçekleştirilir. }\end{array}$ \\
\hline $\begin{array}{l}\text { Tecavüzcülerin çoğu Afrika-Amerikalı ve } \\
\text { mağdurların çoğu Kafkasyalı kadındır. }\end{array}$ & $\begin{array}{l}\text { Tecavüz ırklar arasında değil kendi ırkları dâhilinde } \\
\text { gerçekleşir. Bu mit ırkçılığı yansıtmaktadır. }\end{array}$ \\
\hline $\begin{array}{l}\text { Bir kadının nasıl giyindiği tecavüze } \\
\text { uğrayıp uğramama olasılığını etkiler. }\end{array}$ & $\begin{array}{l}\text { Tecavüzlerin \%90'a kadar çoğunluğu mağdurun nasıl } \\
\text { giyineceği hakkında bilgi olmadan önceden planlanır. }\end{array}$ \\
\hline Yanlış tecavüz raporları sık görülür. & $\begin{array}{l}\text { Tecavüzlerin çoğunluğu rapor edilmemiştir. } \\
\text { Tecavüz raporlarının \%10'undan azı sahte } \\
\text { olarak değerlendirilmektedir. Bu oran diğer } \\
\text { şiddet içeren suçlardaki oranla aynıdır. }\end{array}$ \\
\hline
\end{tabular}

Eker ve Erdener, tecavüze ilişkin mitlerin kabulünün iki önemli duruma dayandığını ifade etmektedir; tecavüzün etkisizleştirilmesinde ve mağdurun damgalanmasına (2011: 61). Her iki durumda da cinsel saldırganlığı gösteren erkeğe yönelik mazeretler sunulur; suç önemsizleștirilir ya da mağdurun "yanlıș" davranıșlarından kaynaklandığı "ima edilir". Özellikle kriminolojinin alt dalı olan kurban bilimci tavır ısmarlama tecavüz davranışı (cinsel ilişkiden son anda cayma) ve ihmal davranışı (kurbanın dış görünümünün saldırıya davetiye çıkarması) üzerinden kurbanı suçlama eğiliminde bulunur (Scully, 2014, s.5556). Nitekim tecavüz haberlerinde kadının mesleğinin, medeni durumunun, bulunduğu yerin ve saatin üzerinde durulması bir bakıma bu mitleri beslemekte toplum nezdinde fail adına "hafifletici sebepler" sunmaktadır. Diğer taraftan 5187 Sayılı Basın Kanunu'nun "Cinsel saldırı, cinayet ve intihara özendirme" başlıklı 20. maddesinde; "Cinsel saldırı, cinayet ve intihar olayları hakkında, haber vermenin sınırlarını aşan ve okuyucuyu bu tür fiillere özendirebilecek nitelikte olan yazı ve resim yayımlayanlar bir milyar liradan yirmi milyar liraya kadar ağır para cezasıyla cezalandırılır. Bu ceza bölgesel süreli yayınlarda iki milyar liradan, yaygın süreli yayınlarda on milyar liradan az olamaz." ifadelerine yer verilmiş olsa da medyada şüpheli ölümler cinsel saldırı, intihar ve cinayet olmak üzere üç belirgin olgu üzerinden sunulmaktadır. Türkiye'de özellikle şüpheli kadın ölümlerinin cinayet öngörüsünden önce intihar öngörüsü ile sunumu Deniz ve arkadaşlarının kadın intiharları ile ilgili yaptığı araştırmanın sonuçları ile ilişkilendirilerek yorumlanabilir. Deniz vd. (2000) Türkiye'deki intiharlarının nedenlerine yönelik yaptıkları araștırmada, intihar olgusunun cinsiyet temelli farklılıkları ile ilgili sonuçlara ulaşmaktadır. Bu doğrultuda; kadınlar, toplumsal baskılar nedeniyle erkekler ise ekonomik nedenlerden bu edimi gerçekleștirmektedir. Medyanın şüpheli ölüm haberlerinde birincil söylem olarak intihar olgusunu kullanması medya dolayımıyla inşa edilen toplumsal baskıların yeniden üretimi olarak yorumlanabilir. Kadına yönelik oluşturulan toplumsal cinsiyet rollerinin en belirgin üretim alanı olan medya, cinsiyet üzerinden oluşturduğu bir neden-sonuç bağı üzerinden bu söylemlere derinlik kazandırabilmektedir. Bununla birlikte, medyanın özellikle intihar haberlerini verirken özendirici etkiden kaçınması gerekliliği uzun yıllardır tartışılmaktadır. Nitekim intihar haberlerinin özendirici etkisi, 1774'te Johann Wolfgang Goethe'nin “Genç Weber'in Acıları" adlı eseri yayınlandıktan sonra eseri okuyan birçok kişinin İtalya, Liepzig ve Kopenhang'ta aynı intihar yöntemini uygulaması sonucu ortaya çıkmış; eser birçok Avrupa ülkesinde yasaklanmıştır (Sudak and Sudak, 2005, s.495).

İntihar olgusunda doğrudan bir taklit ilişkisine dair sayısal veriler mevcuttur. Nitekim ölümcül hastalara yönelik intihar yöntemleri sunan "Son Çıkış" (Final Exit) adlı kitabın yayımlandığı yıl, New York City'deki intihar oranlarının \%313 artarak, \%8'den \%33'e yükseldiği saptanmıştır (Stack, 2002, s.30). 
Medyadaki şiddet ile izleyici saldırganlığı arasında kalıcı bir pozitif ilişki olduğu ortak kanısına rağmen, bu ilişkinin boyutu henüz belirlenmemiştir. Nitekim bazı araştırmacılar medyanın şiddet eylemlerine yol açmadığını; şiddet içeriklerine maruz kalma ile şiddet uygulama arasındaki ilişkinin nedensellik bağına dayanmadığını öne sürmektedirler (Surette and Gardiner-Bess, 2014, s.380). Bu görüşe göre, şiddet eğilimli bireyler şiddet içeriklerini bilinçli olarak aramakta ve tüketmektedirler. Bu doğrultuda medyadaki şiddet içeriklerini azaltmak da suça eğilimi ve suçu azaltmayacaktır. Bununla birlikte, medyanın suç davranışı üzerinde niceliksel olmasa da niteliksel olumsuz etkileri olduğu ve şiddet içeren haber içeriklerinin suça eğilimli kişiler için yeni suç modelleri sağladığı söylenebilir.

90'lı yıllarda İngiliz Tabloid gazetelerinde yer alan cinsel şiddet ve kadın cinayetleri haberlerini inceleyen Cyntia Carter "Sıradan Olan Normalleştiğinde" adlı çalışmasında söz konusu haberlerle cinsel şiddetinin olağandışı bir durumdan çıkarılarak gündelik hayatın doğal bir unsuru olarak normalleştirildiğini ve dış dünyanın kadınlar için tehlikeli bir alan olarak yapılandırdığını ortaya koymaktadır (Carter, 1998). Carter'ın araștırmaları günümüz Türk medyasına uyarlanabilir niteliktedir. Nitekim incelenen haber içeriklerinde mağdura ve şiddete ilişkin her türlü ayrıntının ön plana çıkarılarak kadınlar için bir mağdur prototipi yaratıldığı, benimsenmesi ve kaçınılması gereken davranış kalıplarının șekillendirildiği görülmektedir.

İntihar ve taklit ilişkisinin benzer bir durumu cinayet ve taklit ilişkisinde de gözlemlenmektedir. Edimin haberlerde detaylı sunumu benzer edimlerin yıllar içinde uygulanmasına ve çeşitlik kazanmasına neden olmaktadır. Özellikle beden bütünlügünün kaybı ile ilişkili edimlerin sunumu taklit cinayetlerin popülerlik kazanmasına neden olmaktadır. 2009 yılında meydana gelen Münevver Karabulut cinayetinden sonra ilk 5 yıl içerisinde kadın cinayetlerinde 3 olay beden bütünlüğünün yok edilmesi vakası olarak haberlerde yer alırken son beş yıl içinde kadın cinayetlerinde 29 beden bütünlüğünün yok edildiği vakaya ulaşılmaktadır.

Kadına yönelik şiddet olaylarının haberleştirilmesi gerek suç modelleri oluşturması gerekse oluşturduğu toplumsal cinsiyet kalıpları açısından azami önem taşımaktadır. Bu noktada medyaya oldukça önemli bir görev düşmektedir. İsveç'te intihar olaylarının haberleştirilmesi için medya kılavuzlarının yayınlanmasından sonra dramatik haber başlıklarının kullanımı, \%62'den \%25'e, haberde fotoğraf kullanımı \%43'ten \%8'e, dramatize edilmiş haber içerikleri \%48'den \%14'e düşmüştür (Stack, 2002, s.31). Söz konusu değişikliklerin intihar oranlarındaki gözlemlenen düşüşle doğru orantılı olduğu düşünülmektedir. Kadına yönelik taciz, tecavüz ve cinayet haberleri ise şiddet kaynaklı olmakla birlikte toplumsal cinsiyet kalıplarını da üreten ve pekiştiriren bir özelliğe sahip olduğu için daha büyük bir kitle üzerinde etkili olmaktadır.

\section{Araştırmanın Yöntemi}

Medyatava.com verilerine göre Türkiye'nin en çok okunan gazeteleri, Sabah, Sözcü ve Hürriyet gazeteleridir. Araştırmanın başında söz konusu üç gazetenin incelenmesi amaçlanmıştır. Ancak sahiplik ve ideolojik yapılarındaki benzerlik nedeniyle üç gazetenin de haber dili ve söylem açısından belirgin farklılıklar taşımadı̆̆ı görülmüştür. Çalışmanın kendini tekrarlamaması amacıyla araștırma, söz konusu verilere göre Türkiye'nin en çok okunan gazetesi olan Sabah Gazetesi'nde 01.06.2018-18.06.2019 tarihleri arasında yayınlanan ve konuyla doğrudan ilişkili olan haberlerle sınırlandırılmıştır. Haberler söz 
konusu gazetenin çevrimiçi versiyonu esas alınarak Van Dijk'in eleştirel söylem analizi yöntemiyle incelenmiştir.

\section{Makro Yapı}

\section{Tematik Yapı}

\section{Başııklar (ana, alt ya da yan başıklar)}

Sabah gazetesi 01.06.2018-18.06.2019 tarihleri arasında doğrudan Şule Çet olayına ilișkin 47 haber yapmıştır. Söz konusu haberin başlıklarında enformasyon eksiltimine gidildiği görülmektedir. Haber başlıklarında genel olarak yer ve zaman bilgilerine yer verilmemiş olup okuyucuyu habere çekmek için sansasyonel ifadelere yer verilmektedir. Haber başlıklarında Şule Çet'in ölümünün şüpheli olduğu vurgusu yapılmakta olup okuyucu olayı sorgulamaya yönlendirilmektedir. Haber başlıkları genel olarak haberin ana temasını cinayet şüphesi- yansıtmaktadır. Haber başlıklarının genelinde haber konusu olay Şule Çet davası olarak anılmakta olup sanıkların isimlerine yer verilmemektedir. Ana tema ve başlıklarla oluşturulmaya çalışılan haber retoriğinin mağduru odağa almış izlenimi yaratılmasına rağmen kullanılan haber fotoğrafları ve haber dili ile bu perspektifin kurban/mağdur temelli olmadığı görülmektedir. Özellikle haber metinlerinde mağdurun hayatına dair birçok anekdota yer verilmesine karşın sanıkların isimlerinin bile haber içeriklerinin genelinde kullanılmaması bu değerlendirmeyi güçlendirmektedir.

Haberlerde yan başlıklar ve alt başlıklar kullanılmaktadır. "Lüks plazada dehşet" başlığı daha sonra birçok haberin spotunda da yer almaktadır. Buradaki "lüks plaza" tanımlaması okuyucuyu tecavüz ve cinayet/intihar ile olayın gerçekleştiği mekân arasında nedensel bir ilişki kurmaya yönlendirdiği söylenebilir.

Haberlerin önemli bir kısmının (5, 8, 14, 16, 22, 24, 27, 38, 39, 42, 46 ve 47) "son dakika", "flaş haber" başlıklarıyla verildiği görülmektedir.

38, 42 ve 47 numaralı başlıklarda eksiltili cümleler tercih edilerek okuyucunun merak duygusu körüklenmeye çalışılmaktadır. Söz konusu başlıkların dikkat çekmek amacıyla kurgulanmış sansasyonel içeriklerden oluştuğu ve ana olay hakkında genel bir bilgi vermediği görülmektedir.

3, 15, 17, 35, 37, 38, 41 ve 44 numaralı başlıklar zanlı ve tanık ifadelerinden oluşmaktadır; yer ve zaman bilgilerine yer verilmeyerek kurgulamaya gidilmektedir.

"Akla ziyan ifade”, “Çok kötü şeyler oldu”, "Şule gitti, kalk biz de gidelim”, "Şule Çet'in babası konuştu 'Onları görünce nefes alamadım”,' "Şule Çet davasında gerginlik iddiası: Kızına sahip çıksaydın” başlıkları haber içeriği hakkında bilgi vermekten ziyade ilgi çekmek ve merak uyandırmak amacıyla kurgulandığı söylenebilir.

$20,27,29,31$ ve 34 numaralı başlıklar ise haber konusu olaya ilişkin yeni bilgiler vermekten ziyade yeni fotoğrafları servis etmek amacıyla kullanılmaktadır.

Benzer ya da aynı haber içeriklerinin aynı gün içinde farklı başlıklarla servis edildiği de görülmektedir.

Haber başlıkları toplumsal bir sorun olan kadına şiddetin ve kadın cinayetlerinin magazinsel boyutta ve bireysel bir suç olarak ele alındığını göstermektedir.

Başlıkların önemli bir çoğunluğunda genelleme ve kurgulama tekniğinin hâkim olduğu söylenebilir. 
Tablo 2: Araştırma evreninde yer alan haber başlıkları

\begin{tabular}{|c|c|c|c|}
\hline $\begin{array}{c}\text { Başlık } \\
\text { No }\end{array}$ & Haber Başıı̆ı & Haber Tarihi & Yorum \\
\hline 1. & Lüks plazada dehşet! & 01.06 .2018 & $\begin{array}{l}\text { Belirsiz bir biçimde yer bilgisine yer } \\
\text { verilmekle birlikte kişiler ve zaman } \\
\text { hakkında bilgi verilmemiş; genelleme } \\
\text { ve kurgulamaya gidilmiştir. }\end{array}$ \\
\hline 2. & Şule'nin ölümünde altı karanlık nokta & 12.06.2018 & $\begin{array}{l}\text { Enformasyon eksiltimi yapılmıştır. Haberde bir } \\
\text { eylem bulunmamaktadır. Kurgulama yapılmıştır. }\end{array}$ \\
\hline 3. & Şule'nin yerine ben ölmüş olabilirdim & 14.06.2018 & $\begin{array}{l}\text { Haber konusu olayın dışında yer alan bir } \\
\text { kişinin söylemi başlığa taşınmıştır. Başlıkta } \\
\text { söyleyen kişi ve neden belirsizdir. Enformasyon } \\
\text { eksiltimi yapılmıştır. Bu başlık okuyucuda } \\
\text { merak uyandırmak amacıyla oluşturulmuştur. }\end{array}$ \\
\hline 4. & Şule'nin ölümüne derin soruşturma & 15.06.2018 & $\begin{array}{l}\text { Eylem verilmemiş; kurgulama yapılmıştır. } \\
\text { Yer ve zaman bilgilerine yer verilmemiştir. }\end{array}$ \\
\hline 5. & $\begin{array}{l}\text { Son dakika haber: Şule Çet olayında } \\
\text { gözaltına alınan } 2 \text { şüpheli tutuklandı }\end{array}$ & 14.07.2018 & Başlık haber içeriğini doğrudan yansıtmaktadır. \\
\hline 6. & $\begin{array}{l}\text { Şule Çet'in şüpheli } \\
\text { ölümüne } 2 \text { tutuklama }\end{array}$ & 15.07.2018 & $\begin{array}{l}\text { Haberde bir eylem bulunmamaktadır. } \\
\text { Kurgulama yapılmıştır. }\end{array}$ \\
\hline 7. & $\begin{array}{l}\text { Şule Çet'in katil zanlılarının } \\
\text { ifadesi ortaya çıktı }\end{array}$ & 16.07.2018 & Başlık haber içeriğini doğrudan yansıtmaktadır. \\
\hline 8. & $\begin{array}{l}\text { Son Dakika Haberi: Plazadaki } \\
\text { şüpheli ölüme ilişkin Şule } \\
\text { Çet'in katil zanlılarının şoke } \\
\text { eden ifadesi ortaya çıtı }\end{array}$ & 16.07.2018 & Başlık haber içeriğini doğrudan yansıtmaktadır. \\
\hline 9. & Akla ziyan ifade & 17.07.2018 & $\begin{array}{l}\text { Kişi, yer ve zaman bilgilerine yer verilmeyerek } \\
\text { enformasyon eksiltimi yapılmaktadır. Eyleme } \\
\text { yer verilmeyerek kurgulama yapılmaktadır. }\end{array}$ \\
\hline 10. & $\begin{array}{l}\text { Şule Çet'in avukatından şok } \\
\text { iddia: Delilleri yok ettiler }\end{array}$ & 19.07.2018 & $\begin{array}{l}\text { Bu başlık bir kişinin söylemi } \\
\text { üzerinden üretilmektedir. }\end{array}$ \\
\hline 11. & $\begin{array}{l}\text { Şule Çet olayında 20.kat } \\
\text { görüntüleri bilirkişiye ulaştı }\end{array}$ & 20.07.2018 & Başlık haber içeriğini doğrudan yansıtmaktadır. \\
\hline 12. & Plaza cinayetinin savcısı değiştirildi & 03.10 .2018 & $\begin{array}{l}\text { Genelleştirme ve enformasyon } \\
\text { eksiltimi yapılmaktadır. }\end{array}$ \\
\hline 13. & $\begin{array}{l}\text { Şule Çet davasının seyrini } \\
\text { değiştirecek yeni gelişme }\end{array}$ & 08.11 .2018 & $\begin{array}{l}\text { Haberde bir eylem bulunmamaktadır. } \\
\text { Kurgulama yapılmıştır. }\end{array}$ \\
\hline 14. & $\begin{array}{l}\text { Son dakika haberi: Şule } \\
\text { Çet soruşturmasında Adli } \\
\text { tıp raporu belli oldu }\end{array}$ & 30.11 .2018 & Başlık haber içeriğini doğrudan yansıtmaktadır. \\
\hline 15. & 'Şule gitti, kalk biz de gidelim’ & 01.12 .2018 & $\begin{array}{l}\text { Genelleştirme ve enformasyon eksiltimi } \\
\text { yapılmaktadır. Kişi, yer ve zaman } \\
\text { bilgilerine yer verilmeyerek okuyucunun } \\
\text { merakını uyandıracak sansasyonel bir } \\
\text { başık oluşturulmaya çalışılıaktadır. }\end{array}$ \\
\hline 16. & $\begin{array}{l}\text { Son dakika: Başsavcilıktan üniversite } \\
\text { öğrencisi Şule Çet,in ölümüyle } \\
\text { ilgili soruşturmada flaş gelişme }\end{array}$ & 03.12 .2018 & $\begin{array}{l}\text { Haberde bir eylem bulunmamaktadır. } \\
\text { Kurgulama yapılmaktadır. }\end{array}$ \\
\hline 17. & $\begin{array}{l}\text { Şule'nin ölümüne } \\
\text { ağırlaştırılmış müebbet }\end{array}$ & 04.12 .2018 & $\begin{array}{l}\text { Haberde bir eylem bulunmamaktadır. } \\
\text { Kurgulama yapılmaktadır. }\end{array}$ \\
\hline 18. & $\begin{array}{l}\text { 'İstenen ceza acımızı } \\
\text { biraz olsun hafifletti' }\end{array}$ & 05.12 .2018 & $\begin{array}{l}\text { Genelleştirme ve enformasyon eksiltimi } \\
\text { yapılmaktadır. Kişi, yer ve zaman } \\
\text { bilgilerine yer verilmeyerek okuyucunun } \\
\text { merakını uyandıracak sansasyonel bir } \\
\text { başısık oluşturulmaya çalışılımaktadır. }\end{array}$ \\
\hline
\end{tabular}




\begin{tabular}{|c|c|c|c|}
\hline $\begin{array}{c}\text { Başlık } \\
\text { No }\end{array}$ & Haber Başlığı & Haber Tarihi & Yorum \\
\hline 19. & $\begin{array}{l}\text { Şule Çet davasında } \\
\text { iddianame kabul edildi }\end{array}$ & 18.12.2018 & Başlık haber içeriğini doğrudan yansıtmaktadır. \\
\hline 20. & $\begin{array}{l}\text { Şule Çet'in son görüntüleri } \\
\text { ortaya çıktı }\end{array}$ & 20.12.2018 & $\begin{array}{l}\text { Başlığın haber konusu olayla doğrudan } \\
\text { ilişkisi yoktur. Yeni görüntülerin servis } \\
\text { edilmesi amacıyla kullanılmaktadır. }\end{array}$ \\
\hline 21. & $\begin{array}{l}\text { Şule Çet,in ölümüyle ilgili } \\
\text { dava yarın başlıyor }\end{array}$ & 05.02.2019 & Başlık haber içeriğini doğrudan yansıtmaktadır. \\
\hline 22. & $\begin{array}{l}\text { Son dakika: Şule Çetsin ölümüyle } \\
\text { ilgili davada flaş gelişme: } \\
\text { Sanıklar hâkim karşısında }\end{array}$ & 06.02.2019 & $\begin{array}{l}\text { Haberde bir eylem bulunmamaktadır. } \\
\text { Kurgulama yapılmaktadır. }\end{array}$ \\
\hline 23. & $\begin{array}{l}\text { Şule Çet davası başladı! İddianame: } \\
\text { Cinsel saldırı ve cinayet }\end{array}$ & 06.02.2019 & $\begin{array}{l}\text { Haberde bir eylem bulunmamaktadır. } \\
\text { Kurgulama yapılmaktadır. }\end{array}$ \\
\hline 24. & $\begin{array}{l}\text { Son dakika: Mahkemede dehşete } \\
\text { düşüren ifade! Şule Çet,in ölümüyle } \\
\text { ilgili davanın ilk celsesi görüldü }\end{array}$ & 06.02.2019 & $\begin{array}{l}\text { Başlık iki ayrı ifadeden oluşmaktadır. Birinci } \\
\text { ifadede enformasyon eksiltimi, kurgulama } \\
\text { ve genelleme yapılmaktadır. İkinci ifade ise } \\
\text { haber içeriğini doğrudan yansıtmaktadır. }\end{array}$ \\
\hline 25. & $\begin{array}{l}\text { Şule Çet,in ölümüyle ilgili davada } \\
\text { sanıklara cinayet ve tecavüz } \\
\text { suçlarından ile 39'ar yıl hapis istemi! }\end{array}$ & 06.02.2019 & $\begin{array}{l}\text { Haberde bir eylem bulunmamaktadır. } \\
\text { Kurgulama yapılmaktadır. }\end{array}$ \\
\hline 26. & Şule Çet davası başladı & 07.02 .2019 & Bu başlıkta kişi ve yer bilgileri yer almaktadır. \\
\hline 27. & $\begin{array}{l}\text { Son dakika: Mahkemede dehşete } \\
\text { düşüren ifade! Şule Çet,in ölümüyle } \\
\text { ilgili davanın ilk celsesi görüldü }\end{array}$ & 07.02.2019 & $\begin{array}{l}\text { 06. } 02.2019 \text { tarihli haber aynı başlıkla } \\
\text { yeniden verilmiştir. Başlık iki ayrı ifadeden } \\
\text { oluşmaktadır. Birinci ifadede enformasyon } \\
\text { eksiltimi, kurgulama ve genelleme } \\
\text { yapılmaktadır. İkinci ifade ise haber } \\
\text { içeriğini doğrudan yansıtmaktadır. }\end{array}$ \\
\hline 29. & $\begin{array}{l}\text { Şule Çet’in ölümü davasında } \\
\text { sanıkların yeni görüntüsü ortaya çıktı }\end{array}$ & 07.02.2019 & $\begin{array}{l}\text { Başlığın haber konusu olayla doğrudan } \\
\text { ilişkisi yoktur. Yeni görüntülerin servis } \\
\text { edilmesi amacıyla kullanılmaktadır. }\end{array}$ \\
\hline 30. & $\begin{array}{l}\text { Şule Çet cinayetinin tanıklarının cep } \\
\text { telefonundan bu görüntüler çıktı! }\end{array}$ & 08.02.2019 & $\begin{array}{l}\text { Başlığın haber konusu olayla doğrudan } \\
\text { ilişkisi yoktur. Yeni görüntülerin servis } \\
\text { edilmesi amacıyla kullanılmaktadır. }\end{array}$ \\
\hline 31. & $\begin{array}{l}\text { Şule Çet,in son görüntüleri } \\
\text { ortaya çıktı! }\end{array}$ & 08.02.2019 & $\begin{array}{l}\text { Başlığın haber konusu olayla doğrudan } \\
\text { ilişkisi yoktur. Yeni görüntülerin servis } \\
\text { edilmesi amacıyla kullanılmaktadır. }\end{array}$ \\
\hline 32. & Atılmadan önce boynu kırıldı & 08.02.2019 & $\begin{array}{l}\text { Genelleştirme ve enformasyon eksiltimi } \\
\text { yapılmaktadır. Kişi, yer ve zaman } \\
\text { bilgilerine yer verilmeyerek okuyucunun } \\
\text { merakını uyandıracak sansasyonel bir } \\
\text { başlık oluşturulmaya çalışımaktadır. }\end{array}$ \\
\hline 33. & $\begin{array}{l}\text { Şule Çetsin ölümüne ilişkin } \\
\text { yeni görüntü ortaya çıktı }\end{array}$ & 07.02 .2019 & $\begin{array}{l}\text { Başlığın haber konusu olayla doğrudan } \\
\text { ilişkisi yoktur. Yeni görüntülerin servis } \\
\text { edilmesi amacıyla kullanılmaktadır. }\end{array}$ \\
\hline 34. & $\begin{array}{l}\text { Şule Çet davasında HTS raporu: } \\
\text { 01.48- } 02.16 \text { arasında iletişim yok }\end{array}$ & 08.02.2019 & $\begin{array}{l}\text { Bu başlık raporda yer alan ifadeler } \\
\text { üzerinden üretilmiştir. Kişi, yer ve } \\
\text { zaman bilgisine yer verilmeyerek } \\
\text { enformasyon eksiltimi yapılmaktadır. }\end{array}$ \\
\hline 35. & 'Çok kötü şeyler oldu' & 09.02.2019 & $\begin{array}{l}\text { Genelleştirme ve enformasyon eksiltimi } \\
\text { yapılmaktadır. Kişi, yer ve zaman } \\
\text { bilgilerine yer verilmeyerek okuyucunun } \\
\text { merakını uyandıracak sansasyonel bir } \\
\text { başlık oluşturulmaya çalışılmaktadır. }\end{array}$ \\
\hline 36. & $\begin{array}{l}\text { Şule Çet cinayeti davasında } \\
\text { yeni görüntüler ortaya çıktı }\end{array}$ & 10.02.2019 & $\begin{array}{l}\text { Başlığın haber konusu olayla doğrudan } \\
\text { ilişkisi yoktur. Yeni görüntülerin servis } \\
\text { edilmesi amacıyla kullanılmaktadır. }\end{array}$ \\
\hline
\end{tabular}




\begin{tabular}{|c|c|c|c|}
\hline $\begin{array}{l}\text { Başlık } \\
\text { No }\end{array}$ & Haber Başlığı & Haber Tarihi & Yorum \\
\hline 37. & $\begin{array}{l}\text { Şule Çet’in babası SABAH'a konuştu: } \\
\text { Onları görünce nefes alamadım }\end{array}$ & 10.02 .2019 & $\begin{array}{l}\text { Bu başlık bir kişinin söylemi } \\
\text { üzerinden üretilmiştir. }\end{array}$ \\
\hline 38. & $\begin{array}{l}\text { Şule Çet davasına ilişkin son } \\
\text { dakika gelişmesi! "Şule Çet } \\
\text { soruşturmasında en önemli delil..." }\end{array}$ & 26.03.2019 & $\begin{array}{l}\text { Enformasyon eksiltimi yapılmıştır. } \\
\text { Başlıkta eyleme yer verilemeyerek } \\
\text { kurgulama yapılmaktadır. }\end{array}$ \\
\hline 39. & $\begin{array}{l}\text { Şule Çet davasında son } \\
\text { dakika! Sanığın avukatları } \\
\text { mahkeme salonunda... }\end{array}$ & 14.05.2019 & $\begin{array}{l}\text { Enformasyon eksiltimi yapılmıştır. } \\
\text { Başlıkta eyleme yer verilemeyerek } \\
\text { kurgulama yapılmaktadır. }\end{array}$ \\
\hline 40. & $\begin{array}{l}\text { Şule Çet davasında gerginlik } \\
\text { iddiası! "Kızına sahip çıksaydın" }\end{array}$ & 15.05 .2019 & $\begin{array}{l}\text { Belirsiz bir kişinin söylemi üzerinden } \\
\text { başlık oluşturularak enformasyon } \\
\text { eksiltimi yapılmaktadır. }\end{array}$ \\
\hline 41. & $\begin{array}{l}\text { Bilirkişi: Şule Çetıin } \\
\text { ayakkabısının önce düşmesi, } \\
\text { intihar örüntüsüne aykırı }\end{array}$ & 16.05 .2019 & $\begin{array}{l}\text { Bu başlık bir kişinin söylemi üzerinden } \\
\text { üretilmiştir. Bilirkişinin olayın oluş nedenine dair } \\
\text { öne sürdüğü açıklama başlığa taşınmaktadır. }\end{array}$ \\
\hline 42. & $\begin{array}{l}\text { Şule Çet davasından son dakika } \\
\text { haberi geldi! O ayakkabı aslında... }\end{array}$ & 17.05.2019 & $\begin{array}{l}\text { Kurgulama, genelleştirme ve enformasyon } \\
\text { eksiltimi yapılmaktadır. Kişi, yer ve zaman } \\
\text { bilgilerine yer verilmeyerek okuyucunun } \\
\text { merakını uyandıracak sansasyonel bir } \\
\text { başılık oluşturulmaya çalışılmaktadır. }\end{array}$ \\
\hline 43. & $\begin{array}{l}\text { 'Şule Çet'in intihar ettiğine } \\
\text { dair kanıt yok' }\end{array}$ & 22.05.2019 & $\begin{array}{l}\text { Belirsiz bir kişinin söylemi üzerinden } \\
\text { başlık oluşturularak enformasyon } \\
\text { eksiltimi yapılmaktadır. }\end{array}$ \\
\hline 44. & İntihar olmadığı kanıtlandı & 22.05 .2019 & Genelleme yapılmaktadır. \\
\hline 45. & $\begin{array}{l}\text { Şule Çetsin intihar ettiği iddiasını } \\
\text { Adli Tıp Kurumu raporu yalanladı! }\end{array}$ & 22.05.2019 & Bu başlıkta kişi ve yer bilgileri yer almaktadır. \\
\hline 46. & $\begin{array}{l}\text { Şule Çet’in ölümüyle ilgili } \\
\text { davada flaş gelişme! }\end{array}$ & 17.06.2019 & Kurgulama yapılmaktadır. \\
\hline 47. & $\begin{array}{l}\text { Şule Çet davasında son } \\
\text { dakika gelişmesi! Kaybolan iç } \\
\text { çamaşıı ve ped bulunursa... }\end{array}$ & 18.06.2019 & $\begin{array}{l}\text { Kurgulama, genelleştirme ve enformasyon } \\
\text { eksiltimi yapılmaktadır. Kişi, yer ve zaman } \\
\text { bilgilerine yer verilmeyerek okuyucunun } \\
\text { merakını uyandıracak sansasyonel bir } \\
\text { başlık oluşturulmaya çalışılmaktadır. }\end{array}$ \\
\hline
\end{tabular}

\section{Haber Girişi Spotlar}

Haber spotlarının tamamında 5N1K sorularının cevaplarına bakılmıștır. Spotların genelinde şüpheli ölüm olduğu bilgisi vurgulanmaktadır. Haber spotları birden fazla cümle yapısından oluşmaktadır. Üç haberlerde spot kullanımına yer verilmemekte bu durumda haberin ilk giriş cümlesine bakılarak değerlendirme yapılmaktadır. Haber spotlarında olayın bireysel bir sapkınlık şüphesi olarak ele alındığı ve toplumsal boyutuna yer verilmediği görülmektedir. Haber spotları birbirini tekrar eden yapıları nedeniyle altı içerik üzerinden değerlendirilmektedir. Bu değerlendirmelere dair seçilen örneklere de açılklamaların altında yer verilmektedir.

$1,4,14,16,17,22,23,25,28,31,32,44$ ve 46 numaralı haberlerin spotlarında sanıkların kimlik bilgilerine yer verilmemekte ve haber mağdurun bilgileri dâhilinde sunulmaktadır.

Spot 44: İş beklentisi ile görüşmeye gittiği eski patronu tarafindan öldürüldüğü iddia edilen üniversite öğrencisi hakkında Ankara Adli Tıp Kurumu tarafından hazırlanan raporda Şule Çet'in intihar eğiliminde olmadığı kararına varıldı.

$5,6,7,10,12,21,24,27,29,30,33,35,42$ ve 47 numaralı haberlerin spotlarında $5 \mathrm{~N} 1 \mathrm{~K}$ sorularına cevap üretilmektedir.

Spot 21: Ankara'da, bir plazanın 20'nci katında cinsel saldırıya maruz kaldıktan sonra 
atıldığı öne sürülen Şule Çet>in ölümüyle ilgili davanın görülmesine yarın başlanacak. Sanıklar Çağatay Aksu ve Berk Arand, ayrı ayrı ağırlaştırılmış müebbet ve 39 yıla kadar hapis cezasiyla yargilanacak.

$2,3,9,13,15,18,24,27,33,34,36,37,38,39,40,41$ ve 45 numaralı haberlerin spotlarında avukat, bilirkişi, sanıklar, mağdur yakınlarının ifadelerine yer verilmektedir.

Spot 15: Plazanın 20'nci katından düşerek hayatını kaybeden Şule Çet soruşturmasında tutuklu sanık konuştu: Berk beni uyandırıp, 'Şule camdan atladı gitti, hadi biz de gidelim' dedi.

8 numaralı haberlerin spotunda haber konusu anlatılmakta ancak başlığın içeriğine dair bilgi verilmemektedir. Okuyucu soru cümlesi ile haber gövdesini/metnini okumaya yönlendirilmektedir.

Spot 8: Ankara'da bir plazanın 20. katından şüpheli bir şekilde düşerek hayatını kaybeden üniversite öğrencisi Şule Çet`e iliş̧in son dakika haberleri gelmeye devam ediyor. Ankara'daki vahim olayın, önce intihar olduğu öne sürülmüss; ancak soruşturmanın genişletilmesiyle Şule Çet>in ölümünde büyük bir sir perdesi olduğu ortaya çıkmıştı. Şule Çet>in ölümüne ilişkin tutuklanan Çağatay A. ve Berk A.nın mahkemede verdikleri ifadeleri ortaya çıktı. Peki, iki katil zanlısı bu ifadelerde neler dedi?

19 numaralı haberlerin spotunda başlıkta verilen bilgi aynen tekrar edilmekte ve haber içeriğine dair bilgi verilmemektedir.

Spot 19: Şule Çet>in ölümüyle ilgili hazırlanan iddianame mahkemece kabul edildi.

20, 26, 43 numaralı haberlerde spot kullanılmamaktadır.

\section{Fotoğraf}

"Haberde kullanılan fotoğraflar haber metinlerinin oluşturulmasında temayı destekler ve mesajın etkinliğ̈inin ve inandırıcllğının sağlanmasında önemli bir role sahiptir." (Güneş, 2018, s. 29). Sabah gazetesinde yapılan incelemede bütün haberlerin fotoğraflı olarak yapıldığı tespit edilmektedir. Haber fotoğrafı olarak ölümün gerçekleştiği plazanın fotoğrafları, Şule Çet'in fotoğraflarından oluşan galeriler, zanlının blurlanmış ve açık fotoğrafları ve Şule Çet'in zanlıyla birlikte plazaya girerken görüntülendiği güvenlik kamerasından alınan görüntülerin fotoğrafları da kullanılmıștır. Haberde Şule Çet'in haber konusu olayla ilişkisi olmayan çok sayıda fotoğrafının kullanılması haberin magazinsel boyutta ele alındığını göstermektedir. Zanlıların ve mağdurun olay olmadan önceki son saatlerine ilişkin çok sayıda fotoğrafına yer verilmesi ile Çet'in son dakikalarına ait görüntüler esas alınarak haberin hikâyeleştirildiği söylenebilir. Diğer taraftan Şule Çet'in olayla ilgisi olmayan -yatakta uzanırken verdiği-pozlarının haber fotoğrafı olarak kullanılması mağdurun/kurbanın ihmali üzerinden şekillenen bakış açısının haber metinleri tarafından da üretildiği düşüncesini kuvvetlendirir. 


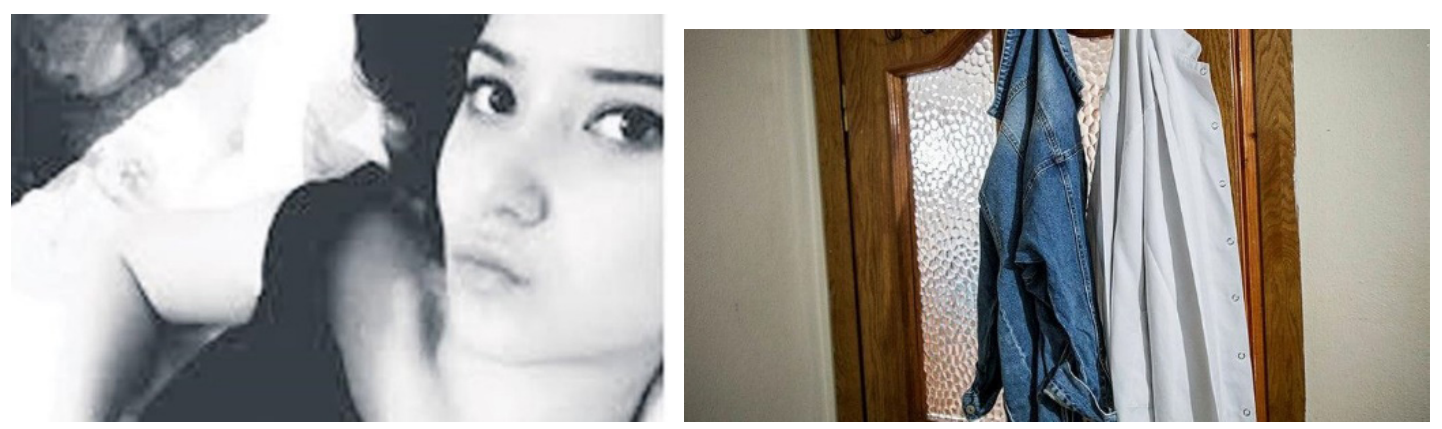

Resim 1: Haber Fotoğrafları

\section{Şematik Yapı}

\section{Durum}

\section{Ana Olayın Sunumu}

Haberlerde ana olay, Şule Çet'in Ankara'da bir plazanın 20. katından düşerek gerçekleșen şüpheli ölümüdür. Sabah gazetesi habere şüpheli bir şekilde bakmakta ve ayrıntıları ön plana çıkarmaktadır. Olay hikâyeleştirilerek sunulmakta, olayın geçtiği yerin "lüks bir plaza" olduğu, Çet'in zanlılarla olan işveren-çalışan ilişkisi ile birlikte geç saatte buluşup alkol aldığı vurgulanarak kurban bilimin mağduru sorumlu tutan bakış açısını (ihmal/ ısmarlama) destekleyen bir söylem üretimi gerçekleștirdiği görülmektedir. Sabah Gazetesinin 15.06.2018 tarihli ve Erkan Çoban imzalı haber metni zanlıların emniyetteki ifadelerinden yola çıkılarak oluşturulan şu ifadeleri barındırmaktadır;

\section{RESTAURANTTA BULUSSMUSSLAR}

Olay akşamı C.A., B.Y. ve bir erkek arkadaşı ile birlikte Çankaya'da lüks bir balık restoranında yemek yiyip alkol aldı. Yemek yedikleri sırada Ç.A., ortağı olduğu ve yakın zamanda kapattıkları Armada AVM'deki restoranda kasiyer olarak çalıştırdıkları fakat issten çlkarmak zorunda kaldıkları Şule Çet ile mesajlaşmaya başladı. Canının çok sıkkın, moralinin bozuk olduğunu söylemesi üzerine Şule Çet>i de restoranda yemek yemeye davet ettiler. O gece yemekte Sule Çet de alkol aldı.Restoranın kapanacağını öğrendikten sonra kalktılar ve arkadaşlarından biri yanlarından ayrıldı. C.A., B.Y. ve Şule Çet birlikte Çankaya>daki lüks plazanın 20. katındaki 58 numaralı ofise geldiler. Burada da alkol almaya devam ettiler.

Zanlıların ifadelerinden alıntılanan bu söylemler okuyucuda olayın bu şekilde gerçekleştiği algısı oluşturabilecek yapıda ve uzunlukta kurgulanmaktadır.

Haber metni içerisinde yer alan "işten çıkarmak zorunda kaldıkları" ifadesi okuyucuları zanlıların iyi niyetle hareket ettikleri fikrini aşılamaktadır. Bununla birlikte hem zanlıların hem de Şule Çet'in alkol aldıkları vurgulanarak alkol tüketimi ve yaşanan olaylar arasında nedensellik bağı kurulmaktadır. Bu nedensellik bağı ile kurbanın olaylara davetiye çıkardığı iması alt metin olarak haberde inşa edilmektedir. Sabah Gazetesi'nin bu konuya ilişkin ilk dört haberinde yapılan "lüks plaza" ve "Ankara'nın en lüks plazası" vurguları bu haber metninde de yapılmaktadır. Söz konusu haberde haber metnine zanlıların ifadelerinden yola çıkılarak devam edilmekte ve tek bir bakış açısı doğruymuş izlenimi yaratılmaktadır.

Haber konusu olayda iş yerine yeni katılan ortak tarafından işten çıkarılan Şule Çet diğer işverenleriyle mesajlaşmış, ona üzülmemesini bir çözüm bulunacağını söyleyen işverenleri onu yemeğe davet etmiştir. Yemeğin ardından zanlıların ofisinin yer aldığı bir plazaya gidilmiştir. Şule Çet gecenin ilerleyen saatlerinde ev arkadaşına "Buradan çıkamıyorum, adam bana takmış. Bırakmıyor, keşke gelmeseydim.” diye mesaj atmıştır. Zanlıların ifadesine göre Şule Çet gecenin sonunda 20. kattan atlayarak intihar 
etmiştir. Olay gazete tarafından şüpheli görülmüş ve zanlıların ifadeleriyle çelişen bilgiler paylaşılmıştır.

Yapılan haberlerin önemli bir kesiminin ise Şule Çet'in ölmeden önceki son görüntülerinin hikayeleștirilmesinden oluştuğu görülmektedir.

\section{Sonuçlar}

Yapılan haberler çerçevesinde oluşan kamuoyu baskısı olayın daha fazla irdelenmesini ve zanlıların tutuklanarak yargılanması sağlamaktadır. Medya gündem yaratma gücünü kullanarak kamuoyunun yaşanan bu olay karşısında bilgi sahibi olmasına ve reaksiyon göstermesine zemin hazırlar. Ancak medya haberi inşa sürecinde kullandığ haberin nasıl gündem olacağını ve kamuoyunda nasıl bir bilinç üretimi yaratacağını da belirlemektedir. Yapılan araştırmada gazetenin kullandığı haber retoriği ile heteronormatif cinsiyet düzeninde kadının geleneksel roller dışında yer aldığı aşamalarda teşvik edici olarak suçlandığı, cinsiyetçi bir dil üreterek kurbanın sorumlu olduğu bir ihmal profili çizdiği söylenebilir.

\section{Ardalan ve Bağlam Bilgisi}

Ardalan bilgisi haber konusu olayın toplumsal, ekonomik veya siyasi boyutunu göstermesi açısından anlamlıdır. Şule Çet'in ölümü üzerine yapılan haberlerde genel olarak olayın toplumsal boyutuna değinilmemekte, olay genç bir kızın işverenleriyle "lüks bir plazaya giderek alkol alması" ve gecenin sonunda yaşadığı öne sürülen taciz, tecavüz ve cinayet olaylarına indirgenmektedir. Ancak medya metinlerinde toplumsal cinsiyet düzeni/rolleri üzerinden oluşturulan sorunlu temsil pratikleri ve haberlerin bireysel niteliklerine vurgu ataerkil toplum düzeninde kadınların yaşadığı ikincilleştirme ya da şiddet sorunlarını önemsizleştirmekte ya da normalleștirmektedir. Hâlbuki bu metinlerde yer alan temsil pratiklerinin ve olayların sosyolojik bağları vurgulanmadan, siyasi ve ekonomik koşulların bu edimlerin gerçekleşmesindeki etkisi belirtilmeden toplumsal cinsiyet rollerine dair eril hegemonik baskıların ortadan kalkması mümkün değildir.

Ardalan bilgisi sadece sosyo-ekonomik yapıyı içermemektedir. Ardalan bilgisinin iyi örülmesi ile aynı zamanda zanlılara dair de bilgiler okuyucuya aktarılmalıdır. Bu bağlamda haber metinlerinde zanlıların geçmişi, karakterleri ve aile yapılarına ilişkin herhangi bir bilgiye yer verilmediği görülmektedir. Bununla birlikte Şule Çet'in annesini kanserden kaybettiği, babasının kalp krizi geçirdiği, üniversite masraflarını karşılamak için çalışmak zorunda olduğu bilgileri ayrıntılı bir biçimde yer almaktadır. Kurbanın yaşamına dair bilgilerin detaylı olarak verildiği ancak zanlıların yaşamlarına dair bilgilere yer verilmeyen haber metinlerinde tarafsızlık ve nesnellik ilkelerinin yer almadığı söylenebilir.

Son olarak Çet'in ölümüne ilişkin ayrıntıları ve şüpheli noktaları içeren haber metinlerinde olayın toplumsal, siyasi ve ekonomik bağlamına ilişkin herhangi bir noktaya yer verilmediği görülmektedir.

\section{Yorum}

Haberlerin genelinde Şule Çet'in avukatı Umur Yıldırım'ın beyanlarına yer verilmektedir. Sanıklar Çağatay Aksu ve Berk Akad'ın ifadeleri, Baba İsmail Çet ve Ağabey Şenol Çet'in yorumları, Çet'in ev arkadaşı Lilia Thorine'in ifadeleri, Cumhuriyet Savcısı Aykut Hüseyin Koca'nın hazırladığı iddianame ve farklı zamanlarda verilen Adli Tıp Raporları haberlerin farklı yorumlarını oluşturmaktadır. 
Baba İsmail Çet'in “onları görünce nefes alamadım” (10.02.2019) sözleri doğrudan haber başlığı olarak kullanılarak haberleştirilmekte, Şule'nin oda kapısına astığı beyaz gömleği ile kot ceketi söz konusu haberde haber fotoğrafı olarak kullanılmaktadır.

\section{Haber Kaynakları}

Haber kaynağı, doğrudan aldıkları ve resmi kaynaklardan elde edilen bilgilerle olayı haberleştiren muhabirlerdir. Haber metinleri, Şule Çet'in katil zanlıları Çağatay Aksu ve Berk Akand'ın ifadeleri ve Çet ailesinin avukatı Umur Yıldırım'ın demeçleri ve babası İsmail Çet, ağabeyi Şenol Çet ve ev arkadaşının sözleri ile desteklenerek ayrıntılara ve konuya ilişkin şüpheli durumlara yer verilmektedir. Gazete soruşturmanın ilerleyen döneminde Adli Tıp Raporlarına ve Savcılık tarafından yayınlanan iddianameye de yer vermektedir.

\section{Mikro Yapı}

\section{Sentaktik Çözümleme}

Haber spotlarında yapılan incelemelerde çoğunlukla edilgen cümleler olmakla birlikte hem etken hem de edilgen cümlelerin kullanıldığı tespit edilmektedir. Haberlerin genelinde kullanılan edilgen yapı eylemi gerçekleștiren öznenin okuyucu tarafından etkisiz algılanmasına neden olmakta ve dikkatleri nesneye/mağdura çekmektedir. Bununla birlikte kadına yönelik şiddet haberlerinde kullanılan edilgen yapı eylemin toplumsal boyutunun da göz ardı edilmesine neden olmaktadır. Diğer yandan, haber başlık, spot ve gövdelerinde olayın sanıklarının ve tarafların söylemlerine birinci ağızdan yer verilmektedir. Aşağıdaki örneklerde görüldüğü üzere haber içerikleri genel olarak karmaşık yapılı cümlelerden oluşturulmaktadır.

\footnotetext{
“Ankara'da bir plazanın 20. katından şüpheli bir şekilde düşen ve olay yerinde hayatını kaybeden Şule Çet>in ölümüne ilişkin yeni gelişmeler ortaya çıktı."

"Ayrıca Şule Çet>in intihar mı ettiği yoksa itildiği ya da öldürüldükten sonra mı atıldığı hususunun da tıbben bilinemediği görüşüne yer verildi."

"Plazanın 20’nci katından düşerek hayatını kaybeden Şule Çet soruşturmasında tutuklu sanık konuştu: Berk beni uyandırıp, 'Şule camdan atladı gitti, hadi biz de gidelim' dedi."

“Bir plazanın 20'nci katından düşerek yaşamını yitiren Şule Çet'in babası İsmail Çet, iki şüpheli için ağır müebbet ve 39'ar yıl hapis talep edilmesini SABAH'a değerlendirdi: 'Bu cezalar, katillere ders olsun" ağırlaştırılmış müebbet ve 39'ar yıla kadar hapis cezası istendi."'

"Gazi Üniversitesi öğrencisi Şule Çet>in ölümüne ilişkin, haklarında "cinayet”, "nitelikli cinsel saldırı" ve "hürriyeti tahdit" suçlarından ağırlaştırılmış müebbet ve 39'ar yıla kadar hapis cezası istemiyle dava açılan 2 sanık, hakim karşısına çıktı."

"Şule Çet>in arkadaşı Trohin, Çet gittikten sonra, geceleyin konuştuklarında bir sıkıntı olmadığını ifade etti."

“Çet'in düşmesinden 18 dakika sonra olayın yaşandığı ofisten çıkan 2 sanığın asansör beklediği sıradaki görüntüleri kameralara yansıdı."
}

Yukarıda örnekleri verilen haber metinlerinde kullanılan karmaşık cümle yapısı eylemin hikayeleștirilmesine ve dramatize edilmesine destek olmaktadır. Haber dilinin sade ve anlaşılır yapıdan uzaklaşması okuyucuya bilgi vermekten ziyade onu bir nevi kurgusal bir metin içerisine çekmektedir. Toplumsal bir sorun olarak ifade edilmesi gereken şiddet olgusu söz konusu haberlerin tamamında okuyucunun merak duygusunu tetikleyecek bireysel bir performans gibi servis edilmektedir. 


\section{Bölgesel Uyum}

Eleştirel söylem analizinde bölgesel uyum haber içeriğini oluşturan cümlelerin nedensel, işlevsel ve referansal ilişkileri çerçevesinde değerlendirilmektedir. Haber içeriğini oluşturan nedensel boyut birbirini takip cümlelerin belirli bir sebep sonuç ilişkisi içerisinde sunulup sunulmadığına işlevsel boyut ardışık olarak dizilen cümlelerin açıklayıcı ifadeler içerip içermediğine referansal boyutta ise cümleler arasında bir bağ olup olmadığına işaret eder (Özer'den aktaran Doruk, 2013, s.124).

“...C.A.'nın da ortak olduğu issyerinde yarı zamanlı çalışıordu. İsyerine sonradan ortak olan kişi, Çet>in işine son verdi. İddiaya göre Ç.A., «Yeniden işe dönmen için buluşup, konuşalım» deyince 28 Mayıssta Şule Çet, C..A. ve onlara katılan 3 kişi ile önce bir restoranda yemek yedi. Genç kız, saat 23.54'e doğru Ç.A. ve B.Y. ile birlikte Çankaya'da bulunan plazanın 20'nci katındaki ofise geçti. Isște ne olduysa da burada oldu. Sabah saat 04.00 siralarında genç kızın düşerek öldüğü belirlendi. O gün Şule Çet>in doğum günüydü. Ankara Cumhuriyet Savcllığı, olaydan sonra kayıplara karışan, 4 Haziran gecesi gözaltına alınan Ç.A. ve B.Y., adli kontrol şartıyla serbest birakıldl."

"Şüpheli C.A., B.Y. olay gecesi yakalandı ve bilgi sahibi olarak ifadelerine başvurulup gönderildi. Soruşturmanın derinleșmesi üzerine C..A., B.Y. şüpheli olarak tekrar gözaltına alındı. Şüpheliler delilyetersizliği nedeniyle adli kontrol şartıyla serbest kaldı. Savcılığın tekrar bilgisine başvurmak istediği şüpheliler yeniden gözaltına alındı. C..A., B.Y. bugün haklarında düzenlenen evraklarla savcı karşısına çıkarılacak."

Yukarıda örnekleri verilen haber metinlerinde kullanılan cümle yapıları incelendiğinde nedensel ve işlevsel boyutun bir arada kullanıldığı görülmektedir.

\section{Sözcük Seçimleri}

Haberlerde kullanılan sözcük seçimleri yansıttıkları gerçek anlam ve yan anlamlar açısından eleştirel söylem analizinin en önemli kısımlarından birini oluşturmaktadır. Nitekim tercih edilen sözcüklerin gerçek anlamları kadar okuyucuda yapacağı çağrışımlar da önemlidir. Sözcük seçiminden haberi oluşturan kişinin/kişilerin kişisel görüşlerinin ve yayın kuruluşunun yayın politikasının izlerini (Güneș, 2018, s. 35) sürmek de mümkündür.

Haber içerikleri oluşturulurken ilk haberden itibaren Şule Çet'in ölümünün şüpheli olduğu üzerinde durulmuştur. Bununla birlikte birçok haberde "düşerek öldügü", az sayıda haberde "atılarak öldüğü" ifadelerine yer verilmiştir.

Haberlerin genelinde haber konusu olayın geçtiği yerin "lüks" bir plaza olduğu vurgusu yapılmış ve olayın geçtiği yerden önce "lüks" bir balıkçıya gidildiği belirtilmiştir. Özellikle ulaşılan görüntüler çerçevesinde genç kızın ve sanıkların olay öncesi ve olay sırasında "alkol aldığı" ifadesine sıklıkla yer verilmiştir. Haberler metinlerde yer alan "lüks" vurgusu diğer yandan mağdurun sıklıkla vurgulanan sosyoekonomik durumuna da işaret etmektedir. Haber konusu olayda "düşük sosyoekonomik statü"de bulunan mağdur zanlılarla birlikte "lüks" bir balıkçıda yemek yemiş, alkol almış ve sonrasında yine "lüks" bir plazaya giderek alkol almaya devam etmiştir. Okuyucuda bütün bunların doğal bir süreç boyunca ilerlemesi gerektiği beklentisi yaratılmaktadır.

Haber metinlerinde tarafların ifadelerine ya da bilirkişi raporlarına dayandırılan birçok söylem mevcuttur. Bu söylemler arasından ilgi çekici görülen ifadeler başlık ve yan başlık olarak kullanılmıştır.

"Onları görünce nefes alamadım"

"Akla ziyan ifade"

"Korkunç gerçek otopsiden çıktı" 
"Şule'nin ölümüyle ilgili şok rapor"

"Şule Çet davasında gerginlik iddiası! 'Kızına sahip çıssaydın"”

Tecavüz, cinsel saldırı ve cinayet ifadeleri sıklıkla kullanılmış; bununla birlikte suçlamalar genel olarak "iddia edildi" ya da "öne sürüldü" gibi tarafsız ifadelerle verilmektedir. 06.02.2019 tarihli haberde "vahşice katledilmesi olayı ile ilgili olarak tutuklandı" ifadeleri kullanılmaktadır. 10.02.2019 tarihli haberde "lüks bir plazanın 20'nci katında tecavüz ve işkenceye uğradıktan sonra öldürülmesi ile ilgili davada" denilmekte; aynı tarihte yapılan bir diğer haberde ise "Doğum gününde üniversite öğrencisi kızı Şule Çet>i, korkunç bir cinayetle kaybeden 63 yaşındaki acılı baba İsmail Çet, SABAH'a konuştu" ifadelerine yer verilmektedir. Vahşice, katledilme, tecavüz, cinsel saldırı, cinayet ifadelerine haber başlıklarının ve içeriklerinin birçok yerinde rastlanmaktadır. "Talihsiz kız" ve "acılı baba" gibi ifadeler de yine haberde kullanılmaktadır. Ancak haberlerin bütünü incelendiğinde bu kelimelerin kullanımının mağdur lehine bir bakış açısı geliştirmeye yeterli olmadığı daha ziyade haberin tabloidleșerek okuyucu ilgisi çekmeye çalışan bir yaklaşım sunduğu görülmektedir.

\section{Haber Retoriği}

Haber içeriklerinin tamamında fotoğraf, bazılarında foto galeri kullanılmaktadır. Kullanılan fotoğraflar çoğunlukla Şule Çet'in haber konusu olayla ilgisiz fotoğraflarıdır. Olay öncesinde Şule Çet'in sanıklarla bir arada alkol alırken ve eğlenirken çekilmiş fotoğrafları haberlerde tamamlayıcı bir unsur olarak kullanılarak okuyucuda nedensonuç ilişkisi kurulması sağlanmaktadır. Haber içerikleri oluşturulurken Bilirkişi ve Adli Tıp Raporlarından destek alınmıştır.

\section{Sonuç}

Ataerkillik ve toplumsal cinsiyet olguları, derinliği toplumlara göre farklılık göstermesine rağmen cinsiyet eșitsizliğinin belirginlik kazandığı kavramlardır. Toplumsal cinsiyet rollerinin baş aktörleri olan kadın ve erkeğe biçilen roller, kalıp yargılar, statüler, imajlar, davranışlar ve görevler, değișen sosyolojik bağlamlara rağmen heteronormatif yapının güçlenmesine ve eril hegemonik sistemin güç kazanmasına yol açmaktadır. "Uygun olan/ normal" (doing gender) kadınlık ve erkeklik statüleri, toplumların belirlediği kültürel değerler çerçevesinde belirlenerek performatif bir yapının oluşmasına neden olmaktadır. Bu performatif yapının oluşmasında itici bir güce sahip olan medya, -haber, dizi, televizyon programı gibi farklı metinlerde- erkeğin etken kadının ise edilgen olduğu bir yapıyı her gün yeniden inșa etmektedir. Özellikle bu metinlerde kadın "kurbanlar", toplumsal normların ya da kabul edilebilir davranış sınırlarının dışında yer aldıklarında şiddeti "hak ettikleri" mesajları üretilmektedir. Diğer yandan kadınlar medyada sıklıkla "tahrik edici" davranışlarından dolayı örtük bir biçimde suçlanmakta, bedenleri ise metaya indirgenerek sömürülmektedir. Bir diğer deyişle, medya, haber ve yorumları aracılığıyla toplumsal önyargıları yeniden üretmekte ve geleneksel kadın imgesini pekiştirmektedir.

Çalışmada kadın imgesinin sunumuna dair Sabah gazetesinin 01.06.2018-18.06.2019 tarihleri arasında doğrudan Şule Çet olayına ilişkin 47 haberi incelenmiştir. Söz konusu haberlerin başlıklarında genel olarak yer ve zaman bilgilerine yer verilmeyerek enformasyon eksiltimine gidildiği görülmektedir. Haber başlıklarında Şule Çet'in ölümünün şüpheli olduğu vurgusu yapılmakta olup okuyucu olayı sorgulamaya yönlendirilmektedir. Haber başlıklarının genelinde haber konusu olay Şule Çet davası olarak anılmakta olup sanıkların isimlerine yer verilmemektedir. Ana tema ve başlıklarla oluşturulmaya çalıșılan haber retoriğinin mağduru odağa almış izlenimi yaratılmasına 
rağmen kullanılan haber fotoğrafları ve haber dili ile bu perspektifin kurban/mağdur temelli olmadığı görülmektedir. Olayın öznesinin kadın olmasından kaynaklı olaydan bağımsız özel hayatına dair detayların aktarıldığı ve gerçekleşen şüpheli ölüm ile bu detaylar arasında neden-sonuç bağının oluşturulmaya çalışılarak cinsiyet baskısının medya tarafından üretildiği söylenebilir.

Sabah gazetesinde yapılan incelemede bütün haberlerin fotoğraflı olarak yapıldığı tespit edilmektedir. Haber fotoğrafı olarak ölümün gerçekleştiği plazanın fotoğrafları, Şule Çet'in fotoğraflarından oluşan galeriler, zanlının blurlanmış ve açık fotoğrafları ve Şule Çet'in zanlıyla birlikte plazaya girerken görüntülendiği güvenlik kamerasından alınan görüntülerin fotoğrafları da kullanılmıștır. Haberde Şule Çet'in haber konusu olayla ilişkisi olmayan çok sayıda fotoğrafının kullanılması haberin magazinsel boyutta ele alındığını göstermektedir. Zanlıların ve mağdurun olay olmadan önceki son saatlerine ilişkin çok sayıda fotoğrafına yer verilmesi ile Çet'in son dakikalarına ait görüntüler esas alınarak haberin hikâyeleştirildiği söylenebilir. Diğer taraftan Şule Çet'in olayla ilgisi olmayan -yatakta uzanırken verdiği- pozlarının haber fotoğrafı olarak kullanılması mağdurun/ kurbanın ihmali üzerinden şekillenen bakış açısının haber metinleri tarafından da alt metinsel bir anlam ifade etmek için kullanıldığı ifade edilebilir.

Yapılan haberler çerçevesinde oluşan kamuoyu baskısı olayın daha fazla irdelenmesini ve zanlıların tutuklanarak yargılanması sağlamaktadır. Medya gündem yaratma gücünü kullanarak kamuoyunun yaşanan bu olay karşısında bilgi sahibi olmasına ve reaksiyon göstermesine zemin hazırlamaktadır. Ancak medya haberi inşa sürecinde kullandığı dille haberin nasıl gündem olacağını ve kamuoyunda nasıl bir bilinç üretimi yaratacağını da belirlemektedir. Yapılan araştırmada gazetenin kullandığı haber retoriği ile heteronormatif cinsiyet düzeninde kadının geleneksel roller dışında yer aldığı aşamalarda teşvik edici olarak suçlandığı, cinsiyetçi bir dil üreterek kurbanın sorumlu olduğu bir ihmal profili çizdiği söylenebilir.

Şule Çet'in ölümü üzerine yapılan haberlerde genel olarak olayın toplumsal boyutuna değinilmemekte, olay genç bir kızın işverenleriyle "lüks bir balıkçıya giderek alkol alması", "lüks bir plazaya giderek alkol alması" ve gecenin sonunda yaşadığı öne sürülen taciz, tecavüz ve cinayet olaylarına indirgenmektedir. Mağdurun sosyoekonomik yapısına dair alt metinler oluşturulmakta ve gerçekleşen olayın ekonomi-politik bağlamı ihmal/ teşvik çerçevesinde değerlendirilmektedir. Ancak medya metinlerinde toplumsal cinsiyet düzeni/rolleri üzerinden oluşturulan sorunlu temsil pratikleri ve haberlerin bireysel niteliklerine vurgu ataerkil toplum düzeninde kadınların yaşadığı ikincilleştirme ya da şiddet sorunlarını önemsizleştirmekte ya da normalleştirmektedir. Hâlbuki bu metinlerde yer alan temsil pratiklerinin ve olayların sosyolojik bağları vurgulanmadan, siyasi ve ekonomik koşulların bu edimlerin gerçekleşmesindeki etkisi belirtilmeden toplumsal cinsiyet rollerine dair eril hegemonik baskıların ortadan kalkması mümkün değildir. Bunlara ek olarak haberlerin genelinde haber konusu olayın geçtiği yerin "lüks" bir plaza olduğu vurgusu yapılmış ve olayın geçtiği yerden önce "lüks" bir balıkçıya gidildiği belirtilmiştir. Özellikle ulaşılan görüntüler çerçevesinde genç kızın ve sanıkların olay öncesi ve olay sırasında "alkol aldığı" ifadesine sıklıkla yer verilmiştir. Haberler metinlerde yer alan "lüks" vurgusu diğer yandan mağdurun sıklıkla vurgulanan sosyoekonomik durumuna da işaret etmektedir. Haber konusu olayda "düşük sosyoekonomik statü"de bulunan mağdur zanlılarla birlikte "lüks" bir balıkçıda yemek yemiş, alkol almış ve sonrasında yine "lüks" bir plazaya giderek alkol almaya devam etmiştir. Okuyucuda bütün bunların doğal bir süreç boyunca ilerlemesi gerektiği beklentisi yaratılmaktadır. 
Haber metinlerinde dengelilik yaklaşımına tam olarak uyulmadı̆̆ı, zanlıların geçmişi, karakterleri ve aile yapılarına ilişkin herhangi bir bilgiye yer verilmediği görülmektedir. Bununla birlikte Şule Çet'in hayatına dair anekdotlar -annesini kanserden kaybettiği, babasının kalp krizi geçirdiği, üniversite masraflarını karşılamak için çalışmak zorunda olduğu bilgileri- ayrıntılı bir biçimde servis edilmektedir. Kurbanın yaşamına dair bilgilerin detaylı olarak verildiği ancak zanlıların yaşamlarına dair bilgilere yer verilmeyen haber metinlerinde tarafsızlık ve nesnellik ilkelerinin yer almadığı söylenebilir.

İncelenen haber örneklerinde kadına yönelik şiddet eyleminin toplumsal boyuttan ziyade bireysel bir suç olarak gösterildiği, bu doğrultuda bağlam ve ardalan bilgilerine yeterince yer verilmediği, kullanılan sansasyonel ifadelerle haber konusu olayın tabloidleştirildiği ve kullanılan ifadeler ve görüntülerle mağdur aleyhine bir bakış açısı oluşturulduğu tespit edilmiștir. Bir toplumsal kurum olarak medya, toplumsal cinsiyet rollerinin oluşmasında ve sürdürülmesinde önemli bir yer arz etmektedir. Özellikle kadına şiddeti içeren haberler söz konusu olduğunda başlık, haber fotoğrafı, kelime seçimi, cümle yapısı vb. mikro ve makro yapıların nasıl kurgulandığı azami önem taşımaktadır. Bu doğrultuda medyanın toplumsal cinsiyet odaklı haber anlayışını reyting/tiraj/tıklanma kaygısının önüne koyması ve toplumsal sorumluluk anlayışı çerçevesinde toplumsal cinsiyet eşitliğini destekleyici bir yayın politikası uygulama hususunda gerekli adımları atması gerekmektedir.

Kadın odaklı habercilik anlayışının oluşturulamaması ve yaygınlaşamaması nedeniyle eril haber dilinin cinsiyetçi söylemlerle kadın erkek eşitliğini güçlendirdiğini, kadını erkeğe bağımlı ve tabi kılmaya çalıștığı, cinsiyetçi uzlaşımlarını güçlendirdiği, ataerkil ideolojiyi yeniden ürettiği ve güçlü kesimlerin söylem pratiklerini meşrulaştırdığı söylenebilir. Toplumsal bir pratik olan söylem, iktidar ilişkileri dolayımıyla egemen ideoloji tarafından beslendiği için bireysel nitelikten ziyade kolektif/toplumsal bir nitelik taşımaktadır. $\mathrm{Bu}$ sebeple haber dili ile normalleştirilen ya da doğallaştırılan anlamlar, cinsiyet asimetrisine yönelik sembolik anlamlar ifade etmektedir. Özellikle kitle medyasının her gün yeniden ürettiği mesajlar, kalıp yargılar içeren cinsiyet kimliğine dayalı imgelerin güçlenmesine ve kolektif hafızada cinsiyet eşitsizliğinin derinleşmesine neden olmaktadır. Dursun'un kadına yönelik şiddet olaylarındaki alternatif habercilik dili önerilerinden yola çıkılarak şüpheli ölüm olayları içinde kadın odaklı habercilik dili oluşturulabilir. Bu noktada, şüpheli ölüm haberlerinde eylem, başlıkta ve haber metninde yeniden üretilecek bir tanımlama ile kategorize edilmemelidir. Öne sürülen olay nedeni, başlıkta yer almamalıdır. Olayda yer alan kadın ve erkek arasındaki hukuki bağ, doğallaştırılarak verilmemelidir. Olayın öznesi kişilerin kendi yaptığı eylemler ile toplumsal konumu (patronu ile aşk yaşayan kadın vs.) bitiştirilmemelidir. Olayın öznesi, acınacak ya da fiziksel özellikleri ön plana çıkarılacak şekilde sunulmamalıdır. Etkin cümle yapıları haberin odağında yer alan eylemin failini açık olarak sorumluluk yüklediği için bu yapılar tercih edilmelidir. Son olarak medya metinleri sansasyonellikten ve abartıdan uzak olmalı ve kadın odaklı habercilik nitelikleri içeren bir dile sahip olarak toplumsal cinsiyet eşitliğinin altını çizmelidir.

\section{Notlar}

1 Heteronormatif cinsiyet düzeni, heteroseksüelliği toplumsal ve doğal norm olarak kabul eden toplumsal cinsiyet yapısını ifade etmek anlamı taşımaktadır.

2 2018-2019 yılında yayınlanan 27 diziye bakıldığında 11 tanesinde (İstanbullu Gelin, Sen Anlat Karadeniz, Eşkıya Dünyaya Hükümdar Olmaz, Can Kırıkları, Bir Zamanlar Çukurova, Avlu, Ay Tutulması, Gülperi, Kadın, Aşk ve Mavi, Siyah İnci) tecavüz mitinin kullanıldığı görülmektedir. 


\section{Kaynakça}

Baştürk Akça, E. ve Ergül, S. (2016). Kitle İletişim Çalışmaları Alanında Toplumsal Cinsiyet Çalışmalarının Gelişimi; Temel Yaklaşımlar ve Çalışmalar Üzerinden Bir Çerçeve Çizme Çabası. Toplumsal Cinsiyet \& Medya Temsilleri içinde (ss. 17-40) İstanbul: Heyamola.

Baştürk Akça, E. \& Tönel, E. (2011). Erkek(lik) Çalışmalarına Teorik Bir Çerçeve: Feminist Çalışmalardan Hegemonik Erkekliğe, Ed. İlker Erdoğan, Medyada Hegemonik Erkeklik ve Temsil içinde (ss.11-39) İstanbul: Kalkedon Yayınları.

Bianet (2018). http://www.haberdetoplumsalcinsiyet.org/haber-ve-soylesiler/haberler/ erkek-siddeti-mayis-2018/ (Erişim Tarihi 10.06.19).

Bouerdieu, P. (2015). Eril Tahakküm. İstanbul: Bağlam.

Budak, H. Küçükşen K. (2018). Türkiye'nin Sosyal Transformasyon Sürecinde Y Kuşağının 'Toplumsal Cinsiyet Rolü' Tutumları. Elektronik Sosyal Bilimler Dergisi, Bahar, 17 (66), 561-576.

Butler, J. (2014). Cinsiyet Belası. İstanbul: Metis.

Carter, C. (1998). When the Extraordinary Becomes Ordinary: Everyday News of Sexual Violence in Carter, C., G. Branston and S. Allan (eds) News, Gender and Power. London: Routledge.

Connell, R. W. (1998). Toplumsal Cinsiyet ve İktidar. Cem Soydemir (Çev.). İstanbul: Ayrıntı.

Connell, R. W. (2017). Toplumsal Cinsiyet ve İktidar: Toplum, Toplum, Kişi ve Cinsel Politika. İstanbul: Ayrıntı Yayınları

Deniz, İ., Ersöz, A. G., İldeş, N. ve Türkaslan, N. (2000). “1995 - 2000 Yılları Resmi Kayıtlarından Batman'da Gerçekleșen İntihar ve İntihar Girișimleri Üzerine Bir İnceleme". Aile ve Toplum Eğitim ve Araștırma Dergisi, 1, 27-48.

Deniz Ş. \& Korap Özel E. (2015). Tecavüzün Haberleștirilmesinde Etik Sorunlar: “5N $1 \mathrm{~K}$ Yetmez, Bir de Vicdan Gerek". Gaziantep University Journal of Social Sciences. 14 (4), 721-75.

Doruk, Ö (2013). Disiplin Toplumu ve Haber Söylemi: Gökkuşağı Derneği'nce Yapılması Planlanan Yürüyüşün Engellemesine İlişkin Haberlerin Çözümlenmesi. Gümüşhane Üniversitesi İletişim Fakültesi Elektronik Dergisi, 2(1), 106- 132.

Dursun, Ç. (2008). Kadına Yönelik Aile İçi Şiddet ve Haber Medyası: Alternatif Bir Habercilik. Ankara: Kadın Statüsü Genel Müdürlügü.

Eker T. \& Erdener E. (2011). Tecavüze İlişkin Kültürel Mitler ve Mitlerin Kabul Edilmesine Etki Eden Faktörler. Türk Psikoloji Yazıları, Aralık.14 (28), ss. 60-72

Erol, D. D. (2014). Toplumsal Cinsiyet Açısından Türkiye Yazılı Basınında Şiddet Haberleri ve Haber Fotoğrafları. H. Kuruoğlu ve B. Aydın (Ed.), Toplumsal Cinsiyet ve Medya içinde, (ss. 31-67) Ankara: Detay.

Güneş, A. (2018). Yazılı Basında Haber Söylemi: 24 Haziran 2018 Cumhurbaşkanlığı ve Milletvekili Seçim Haberlerinin Çözümlenmesi, İstanbul Arel Üniversitesi İletişim Çalışmaları Dergisi,6 (12), 1-42.

Lipman-Blumen, J. (1976). Toward a Homosocial Theory of Sex Roles: An Explanation of the Sex Segregation of Social Institution Sings 1(3), 15-31. 
Kandiyoti, D. (2007). Cariyeler, Bacılar, Yurttaşlar: Kimlikler ve Toplumsal Dönüşümler, İstanbul: Metis.

Mathieu, N. C. (2009). Cinsiyet ve Toplumsal Cinsiyet, H. Hırata vd. (Der.) Eleştirel Feminizm Sözlüğü. İstanbul: Dipnot.

Meuser, M. (2004). "Homosociality". Men and Masculinities: A Social, Cultural and Historical Encyclopedia Volume I: A-J (Der.) Michale Kimmel ve Amy Aronson. Santa Barbara, Dever ve Oxford:ABC-Clio. 396-397.

Oakley, A. (2016). Sex, Gender and Society, Routledge, London and Newyork.

Okray, Z. (2018). Türk Basınında Kadına Yönelik Tecavüz Haberlerinin Eleştirel Söylem Çözümlemesi Modeliyle İncelenmesi. Sosyoloji Araştırmaları Dergisi, Cilt 21 (1), 190-238.

Özbay, C. (2013). Türkiye'de Hegemonik Erkekliği Aramak. Doğu-Batı Düşünce Dergisi:Toplumsal Cinsiyet 63 (1), 185-204.

Özer, Ö. (2008). İdeolojik Atmosferin Kapsama Alanı: Bozüyük Olaylarının Ortadoğu ve Ülkede Özgür Gündem Gazetelerinde Sunumu Örneğinde Haber Söyleminde Yapılan İdeolojik Üretime İlişkin Yeni Bir Çözümleme, E. Dağtaş (Der.), Türkiye'de Sivil İtaatsizlik Toplumsal Hareketler ve Basın içinde (ss. 377-432). Ankara: Ütopya.

Polat, O. (2016). Şiddet. Marmara Üniversitesi Hukuk Fakültesi Hukuk Araştırmaları Dergisi. C. 22 (1), 15-34.

Sancar, S. (2009). Erkeklik: İmkânsız İktidar 'Ailede, Piyasada ve Sokakta Erkekler'. İstanbul: Metis.

Saygılıgil, F. (2016). Toplumsal Cinsiyet Tartışmaları. Ankara: Dipnot.

Scully, D. (2014). Cinsel Şiddeti Anlamak: Tutuklu Tecavüzcü Erkekler Üzerine Bir İnceleme. İstanbul: Metis.

Stack, S. (2002). Media Coverage as a Risk Factor in Suicide. Injury Prevention 8 (Suppl IV):iv30-iv32.

Sudak H. S. And Sudak D. M (2005). The Media and Suicide. Academic Psychiatry, 29:5, November-December. http://ap.psychiatryonline.org, 19.11.2019.

Surette R. and Gardiner-Bess R. (2014). Media, Entertainment and Crime Prospects and Concerns. The Routledge Handbook of International Crime and Justice Studies. Edited by Bruce A. Arrigo and Heather Y. Bersot. New York: Routledge. pp.373-396

Wood, J. T. (2004). Gendered Media: The Influence of Media on Views of Gender. Julie T. Wood (Ed.), Gendered Lives: Communication, Gender, and Culture içinde (ss. 231244.). Chapter 9.

www.who.int https://www.who.int/violenceprevention/approach/definition/en/ Çevrimiçi 19.11.2019.

Van Dijk, T. (2003). Söylem ve İdeoloji Çokalanlı Bir Yaklaşım. B. Çoban \& Z. Özarslan (Der.), Söylem ve İdeoloji mitoloji, din, ideoloji içinde (ss. 13-113) İstanbul: Su.

Vatandaş, C. (2007). Toplumsal Cinsiyet ve Cinsiyet Rollerinin Algılanışı. Sosyoloji Konferansları. 1 (35), 29-56. 
Yardım, G. Doğruel, H. (2019). Eleştirel Söylem Çözümlemesi Bağlamında Haber Metinlerinin İncelenmesi: Pippa Bacca Cinayeti Örneği*, Erciyes İletişim Dergisi Ocak/January, 6 (1), 137-148.

Yeşil, F. Yıldırım, A. (2018). Toplumsal Cinsiyet ve Medyadaki Söylemi: Evlilik Programları. Selçuk Üniversitesi İletişim Fakültesi Akademik Dergisi, 12 (1), 232- 254. 


\title{
Gender and the Media: Critical Discourse Analysis of the News on the Suspect Death of Şule Çet
}

\author{
Zeynep Burcu Şahin (Asst. Prof. Dr.) \\ Yıldız Derya Birincioğlu (Asst. Prof. Dr.)
}

\section{Extended Abstract}

The concept of gender can be called as stereotypes, judgments and prejudices that an individual acquires in relation to his/her biologycal sex in the socialization process. Gender is a socio-cultural phenomenon that occurs with the individual's socialization process. Gender roles are produced and supported by all social institutions, especially the family, in a way to support each other. Education, law, religion and the media reinforce and constantly reproduce the social roles that were first sown by the family.

Violence, which is a social problem, is often removed from the economic, political and cultural context of society by being reduced to individual reasons (personal characteristics, mental instability, personal economic problems, unemployment, etc.) while it's being reported. In gender-based violence, the roles that society assigns to women and men and the patterns of behavior deemed appropriate play a dominant role. In this context, the role of the media that reproduces and affirms these patterns is very important when reporting the rape crimes in the adoption and stereotyping of gender roles.

In this context, the study includes the analysis of the news in the digital version of Sabah newspaper between the dates 01.06.2018-18.06.2019 on the suspicious death of Şule Çet, who was put on the agenda of the new media and then settled on the mainstream media agenda, either. On 28 May 2018, Şule Çet met her employers at a plaza in Çankaya and died at the end of the night by falling from the 20th floor of the plaza. The death, which was considered suspicious by the newspapers, was brought up on a periodic basis with the leadership of new media during the last year and public pressure was put on behalf of the prosecution of the suspects. The aim of this study is to analyze the content of news that appears victim-based at first glance through the analysis of critical discourse analysis and to present suggestions for gender-oriented journalism by revealing gender inequalities built into the content.

The study is based on Van Dijk's method of critical discourse analysis. Critical discourse analysis, which is used to uncover data on gender-oriented journalism, provides implicit meaning and ideologies in language forms and creates space to examine the relationship between power, discourse and ideology through media contents. When it comes to news involving violence against women, the title, news photo, word selection, sentence structure, etc. how micro and macro structures are constructed is of utmost importance. Public pressure created within the framework of the news provides further investigation of the incident and the arrest and prosecution of the suspects. Using the power of creating the agenda, the media paves the way for the public to be informed and react to this event. However, the media determines how the news will be on the agenda with the language it uses in the process of building the news and how it will create a consciousness production in the public. In the research, it can be said that the news rhetoric used by the newspaper and the heteronormative gender order in which women are accused as incentives in 
other than traditional roles, produce a sexist language and draw a profile of neglect that the victim is responsible for.

Patriarchy and gender phenomena are concepts in which gender inequality gains prominence, although the depth varies according to societies. The roles, stereotypes, statuses, images, behaviors, and duties assigned to men and women, the main actors of gender roles, lead to the strengthening of the heteronormative structure and the strengthening of the masculine hegemonic system despite changing sociological contexts. Doing gender femininity and masculinity status is determined within the framework of cultural values determined by societies, leading to the formation of a performative structure. The media, which has a driving force in the formation of this performative structure, rebuilds a structure in which men are active and women are passive in different texts such as news, TV series and television programs.

Particularly in these texts, the message "women 'victims' deserve violence when they are outside social norms or acceptable behavior" is produced. On the other hand, women are often implicitly blamed for their "provocative" behavior in the media, and their bodies are reduced to commodities and exploited. In other words, the media reproduces social prejudices through its news and comments and reinforces the traditional image of women.

It can be said that due to the inability to create and spread women-oriented journalism, the masculine news language strengthens gender inequality with gender discourses, tries to subordinate women to men, reinforces sexist compromises, reproduces patriarchal ideology and legitimizes discourse practices of powerful segments.

Discourse, which is a social practice, has a collective / social character rather than an individual quality as it is nourished by the dominant ideology through power relations. For this reason, the normalized or naturalized meanings of the news language have symbolic meanings for gender asymmetry. In particular, the mass media's daily reproduction of messages leads to the strengthening of images based on gender identity, including stereotypes, and deepening of gender inequality in collective memory.

At this point, action in suspicious death news should not be categorized by a description that will be reproduced in the headline and in the news text. The cause of the proposed event should not be included in the title. The legal bond between men and women involved in the incident should not be given as naturalized. The subject of the incident should not be connected with the actions of the people themselves and the social position (the woman who lives in love with her boss etc.). The subject of the incident should not be presented in such a way that the pitiful or physical characteristics are highlighted. Active sentence structures should be preferred because they place explicit responsibility on the perpetrator of the action in the focus of the news. Finally, media texts should be free from exaggeration and underline gender equality with a language that includes women-oriented journalistic qualities. In this context, the media should put the gender-oriented news approach in front of rating / circulation / click concerns and take the necessary steps to implement a broadcasting policy that supports gender equality within the framework of social responsibility.

Keywords: Media, Violence against Women, Critacal Discourse Analysis, Gender. 
